\title{
Shaping the EAEU's Institutional Framework for Banking Regulation: Perspectives and Risks ${ }^{1}$
}

\author{
E. Dzhagityan
}

Eduard Dzhagityan - PhD, Associate Professor, School of World Economy, Faculty of World Economy and International Affairs, National Research University Higher School of Economics; 20 Myasnitskaya Str., Moscow, 101000, Russian Federation; E-mail: edzhagityan@hse.ru

\begin{abstract}
The institutional aspect of post-crisis banking regulation reform (Basel III) remains unsettled, and as such undermines regulators' efforts to shape a seamless platform for international financial intermediation. The lack of global acceptance of the Basel III standards amid the internationalization of banking activities is one of the main reasons for regulatory asymmetries which are difficult to handle at the national level. In this context, the efforts of governments and financial regulators are a central core of their policy in protecting banking sectors from systemic risks. It becomes imperative to bring together national mechanisms of banking regulation and to develop a regional system of regulatory institutions, as is evidenced by the single supervisory mechanism in the eurozone countries.

Strengthening stress-resilience of the national banking sectors in the Eurasian Economic Union (EAEU) and the expansion of banking activities to the Eurasian economy will require a conceptual framework of the EAEU banking regulation system. However, different regulatory regimes in EAEU states along with the lack of supranational regulatory institutions may slow the progress of the Eurasian mechanism of banking regulation. This means that operationalization of the EAEU regulatory mechanism will depend on whether the mini-Basel III format as a methodological hub of regionalization and supranationalization will act as an enabler of a resolution to the regulatory trilemma of the feasibility, relevance and opportunities of supranationalization.

The institutional aspect of mini-Basel III is intrinsically linked to the integrity and consistency of the supranational authority for regulation of EAEU financial markets being an authority documented in the treaty on the EAEU; however, the costs of regulatory alignment may exceed the advantages of a single-institution regulatory architecture owing to the existent and tacit risks from the heterogeneity of the national regulatory models. Stemming from the complex financial sector environment that falls short of valid and reliable institutional fundamentals, this article proposes alternative scenarios for the EAEU regulatory mechanism that could be sought for optimization of regulatory logistics and algorithms of regulatory alignment. Based on systematization of the benefits and weaknesses of each of the scenarios as well as on a comparative analysis as to whether the proposed scenarios would ensure a continuum of financial intermediation and financial stability, this article concludes that currently there are no priority approaches to the design of a supranational institutional system in the EAEU. At the same time, the identical structure of national banking sectors together with the least expensive scenario approach could underpin the process of regulatory supranationalization; however, to secure the integrity of the EAEU supranational authority, it should be complemented with an authority that would be responsible for the coordination of EAEU-wide regulatory alignment.
\end{abstract}

Key words: international banking regulation; banking regulation institutes; Basel III; mini-Basel III; integration; supranationalization; systemic risks; Eurasian Economic Union (EAEU)

For citation: Dzhagityan E. (2019) Shaping the EAEU's Institutional Framework for Banking Regulation: Perspectives and Risks. International Organisations Research Journal, vol. 14, no 2, pp. 212-237 (in Russian and English). DOI: 10.17323/1996-7845-2019-02-10.

${ }^{1}$ The editorial board received the article in April 2018.

This article is an output of a research project entitled "Economic and Institutional Aspects of Shaping the EAEU Banking Regulation Mechanism" implemented as part of the Individual Research Programme of the Faculty of World Economy and International Affairs at the National Research University Higher School of Economics (HSE). 


\section{The New Institutional Framework for International Banking Regulation}

\section{The Aftermath of Banking Sector Deregulation}

The large-scale economic meltdown at the turn of the 2010s, which affected almost all global financial markets, signified a principally new phenomenon - the globalization of macro level instability. A variety of factors underlying the crisis gave birth to plenty of expert opinions and academic discussions, and there was little doubt that the crisis was an outcome of a simplified approach to financial regulation ${ }^{2}$ that had lasted almost 30 years, beginning in the late 1970s. Neglect of the fundamental principles of financial supervision and misunderstanding of the risks of deregulation rolled back the ability of banking regulators to effectively withstand crisis developments and economic downturns.

The failure of deregulation also exposed gaps and problems in the institutional structure of banking regulation. ${ }^{3}$ Regardless of the regulatory framework, ${ }^{4}$ the mechanisms and instruments of international and national regulators failed to meet the objectives of banking regulation and supervision $^{5}$ and did not resolve mounting challenges in the financial sector. The ongoing process of diversification and sophistication of financial products and services, the lack of transparency of the operating models of credit institutions, and breakthrough banking technologies clashed with the outdated and maladjusted mechanism of financial supervision. The domination of the short-termism ideology ${ }^{6}$ to the detriment of stress resilience policy eroded the balance between profitability and risk, which adversely affected financial stability. Obviously, the increasing regulatory inconsistencies amid moderated financial intermediation and increased interconnectedness of financial institutions did contribute to information asymmetry ${ }^{7}$ in global financial markets, which logically resulted in the end of the deregulation era.

\footnotetext{
${ }^{2}$ Hereinafter, the terms "regulation," "financial regulation," and "banking regulation" have similar meaning and imply a set of measures initiated by the Group of 20 (G20) (governments and central bank governors of 19 countries and the EU) in the framework of the post-crisis recovery. The use of different terms depends on the respective context.

${ }^{3}$ Hereinafter, the "institutional structure of banking regulation" means the organizational and functional specifics of designated authorities, including central banks, which are assigned the responsibility of regulation and supervision of financial markets and financial market institutions.

${ }^{4}$ The institutional framework of regulation is determined by specific functions that are assigned to the authorities of national/regional regulation of the banking sector. Regulatory functions may be assigned to a central bank (a mono-institutional structure of banking regulation and supervision), although this framework may imply additional costs associated with minimization of conflict of interests between monetary and banking regulation policies, including the issues of independence of the assigned authority. The regulatory responsibilities may also be distributed among different regulatory institutions; however, part of the responsibilities may be assigned to the central bank (e.g. macro prudential regulation), and the other part to the specialized regulatory authorities (a multi-institutional structure of banking regulation and supervision). A "divided" specialization implies a higher level of independence and transparency of regulatory policy, as well as minimal risks related to government intervention in banking regulation policy.

${ }^{5}$ Hereinafter, for ease of understanding the terms "banking regulation," "prudential banking supervision," and "banking supervision" are associated with the term "banking regulation" unless the relevant context requires additional clarification or unless otherwise specified.

${ }^{6}$ This mostly refers to prioritization of benefits from profit-making over the risks, which ultimately may severely downplay the profit-making outcome, i.e. undermining or even neglecting qualitative factors underlying routine banking activity.

${ }^{7}$ Information asymmetry is among the factors that exacerbate systemic risks and ultimately - financial crises. Some experts (see, for example, Mwenda [2006, p. 4]) suggest regulation of information exchange in the banking industry and integration of this aspect into the system of international banking regulation.
} 
Incongruity between the institutional framework of regulation, on the one hand, and the needs of economic development and growth and the challenges of financial globalization, on the other, has been resolved by shifting the post-crisis regulatory priorities to the area of crisis management and financial stability. ${ }^{8}$ At the same time, the development of an efficient regulatory mechanism is constrained by the variety of operating models of credit institutions and, accordingly, the extent of their ability to adapt themselves to the specifics of contemporary supervision standards, while being determined by the objectives of macro-financial management. The balanced mechanism of regulatory policy also depends on the extent of independence of regulatory institutions. It is clear that the imbalance between financial intermediation and regulation will reduce the efficiency of banking activity and will remain a source of instability [Erol, Ordoñez, 2017], thus undermining efforts on international coordination of regulatory reform ${ }^{9}$ and impeding its internationalization.

\section{Inconsistencies and Risks in the Contemporary International Banking Regulation Order}

In the Russian and foreign academic literature, issues of international banking regulation are mainly addressed from economic perspectives, which at first glance may seem reasonable given the overwhelming scale of the reform and the macroeconomic uncertainty that challenges its implementation. However, in the context of banking evolution, issues of economic cycles and their synchronization with regulation ${ }^{10}$ are necessary but not sufficient for ensuring the stress resilience of banks and banking systems. Given the higher degree of internationalization of financial intermediation and institutional interdependence in the global financial markets, bringing the banks back to their pre-crisis power as driving forces of the economy can hardly be considered in isolation from the issue of the coordination of international regulatory reform, including regulatory institutions. ${ }^{11}$

Currently, the international level of banking regulation consists of a system of regulatory authorities (but not institutions) whose responsibilities are limited to the coordination of regulatory reform and the calibration of regulatory policy, as well as recommendations for the regulators at the national level:

- the Group of 20 (G20) as the "supreme authority" for the coordination of international regulatory reform and its main driving force;

${ }^{8}$ The system of international regulation that evolved in the post-crisis period is a sweeping change in economic policy driven by common objectives aimed at more rigorous measures to minimize systemic risks and, accordingly, risks of crisis developments due to the stabilization effect when regulating the banking sector in order to restore the pre-crisis key performance indicators of banks, as well as ensuring their sustainability and the continuity of financial intermediation.

${ }^{9}$ Known as Basel III, it is a set of standards and recommendations for banking supervision developed by the Basel Committee on Banking Supervision (BCBS) in 2010-11 aimed at reduction of risk exposure in the financial sector by the introduction of a more rigorous minimum capital adequacy ratio, liquidity, leverage, stable funding, long-term management of systemic risks and a higher level of transparency. Basel III should have been completed before 1 January 2019.

${ }^{10}$ Based on the objective of financial stability, the effectiveness of regulatory reform depends on synchronization of regulatory and supervisory cycles with economic and financial cycles. The implementation of this objective is linked to the use of a mixture of flexible standards of prudential banking supervision and macro prudential regulation tools (see, for example E. Dzhagityan [2017a] for more details on macro prudential policies). This approach not only facilitates the adaptation of banks to regulatory transformations but also reduces the dependence of the banking sector on adverse externalities.

${ }^{11}$ Hereinafter, regulatory institutions include national/supranational institutions of banking regulation and authorized institutions at the international level, which are not regulatory institutions by status but are assigned to coordinate the reform with national/supranational institutions of banking regulation. 
- the Financial Stability Board (FSB) as the coordinating body for the international regulatory reform process; and

- the Basel Committee on Banking Supervision (BCBS) ${ }^{12}$ as the methodological and technological hub of international regulatory reform and modernization of the regulatory mechanism (also known as Basel III).

It is difficult to assess the efficiency of these international authorities, since the principles and standards of Basel III have been implemented only in a few countries, while regulatory innovations depend on whether the regulatory transformation is sought at the national level. The lack of an institutional platform for international banking regulation challenges the concept of financial stability and constrains regulatory changes, thus undermining the integrity of the reform. Inconsistency of institutional aspects of the new regulatory order amid diversity of regulatory instruments seriously affects the ability of banking regulators to mitigate systemic risks, not only in the national/regional financial markets but also globally. ${ }^{13}$

The lack of international regulatory institutions leaves open the issue of the effectiveness of the international system of banking regulation. Among the consequences of a poor institutional framework is the ambiguity of the institutional affiliation of banking regulation at the national level: unlike monetary policy, which is solely assigned to a central bank, ${ }^{14}$ banking regulation can be assigned both to a central bank (the so called "mono-institutional" regulatory framework) and to specialized institutions ("multi-institutional" regulatory framework ${ }^{15}$ ). The mono-institutional framework implies extra costs associated with intra institutional conflicts of interest, while the multi-institutional framework comes with extra costs associated with interinstitutional regulatory coordination. There are also a number of other specifics related to the organizational design of banking regulation (see, for example, D.T. Llewellyn [2006, p. 4]).

The absence of a single approach to the institutional affiliation of banking regulation and the dearth of international/supranational regulatory institutions inevitably weakens the synergetic effect of reform, diminishing its potential and fuelling reform asymmetries, including:

- the increase of the gap between the national principles of effective banking supervision and those stipulated by Basel III [BIS, 2012a], which blurs the perspectives on the alignment of regulatory standards at the national and international levels [Goldbach, 2015];

- the risk of regulatory arbitrage as a result of differences in national regulatory regimes and oversight standards; ${ }^{16}$

- the regulatory capture phenomenon due to the interconnectedness of regulators, economic actors and financial markets [Tsingou, 2007; Underhill, Zhang, 2008]; and

${ }^{12}$ The BCBS is not a supranational authority, its decisions are not legally binding and it cannot impose penalties or any other sanctions [BIS, 2018].

${ }^{13}$ Thus, despite the efforts of international regulators to reduce the adverse effect of large banks for the banking sector and the economy at large, their aggregate assets grew by $40 \%$ over the period 2005-14. Further, the share of their assets to GDP has also increased [World Bank Group, 2018, p. 10].

${ }^{14}$ Hereinafter, for the convenience of the readers, the term "central bank" is also applicable to other institutions with central bank functions (national bank, reserve bank, monetary agency, monetary administration, etc.)

${ }^{15}$ With a multi-institutional regulatory structure, the central bank retains regulatory/supervisory functions (fully or partially), or regulation of financial markets can be assigned to other specialized institutions.

${ }^{16}$ Regulatory arbitrage is a product of the different regulatory regimes which, in turn, implies higher profits that are often associated with speculation in financial markets. At the same time, a loose regulatory regime is associated with higher operational risks, which can later become a source of instability in the banking sector and trigger the cross-border transmission of systemic risks. The regulatory arbitrage policy is mainly used by the systemically important financial institutions operating in the global financial markets. Another aspect of regulatory arbitrage is attributable to macro level risks: the higher the risk level, the more difficult it is for banks to raise extra capital from the market due to its rising cost and vice versa. 
- the long-standing uncertainty of the concept of systemically important financial institutions (SIFIs) ${ }^{17}$ (particularly in the European Union), which encourages prioritization of national interests to the detriment of the globalization of reform [Spendzharova, 2017].

The unsettled issues of post-crisis regulation amid the weaknesses of its institutional framework is one of the main reasons regulators have been unable to reduce the assets of SIFIs, including global systemically important banks (G-SIBs), to a level that does not pose a threat to financial stability (Table 1). Despite the decline of the share of their assets to the total assets of national banking sectors (except for Russian banks) and the numerous efforts of regulators to bring their operating models to traditional banking activity (by de-emphasizing non-financial assets), that level remains high while their assets continue to grow (except for British banks). ${ }^{18}$ It seems that the unresolved issue with the domination of the largest banks is one of the failures of reform, given that it was finalized by 1 January $2019 .{ }^{19}$

According to experts, the higher-than-expected costs of regulatory compliance stem from the "under-institutionalization" of the regulatory framework. The growing costs mainly affect the large banks that are leaders in attracting deposits and securities trading, which in turn require additional expenses for the redesign and adjustment of their operating models [Spendzharova et al., 2016]. However, cost savings depend on the flexibility of the approach of the national regulators to the standards and recommendations of Basel III when implementing the current regulatory standards [de Chiara, Livio, Ponce, 2018], i.e. the standards applicable at the national level.

In this regard, it is clear that the efficiency of the post-crisis regulatory regime is determined by a combination of the principles of international reform and the interests of the national banking sectors. This is corroborated by findings on the regulatory system with the focus on the stress resilience of banks and the effectiveness of their role as the creditors of the economy [Erol, Ordoñez, 2017]. In other words, this regime is a kind of regulatory equilibrium, meaning that the ability of banks as creditors coincides with the needs of the economy for credit resources. However, for a number of reasons associated with more rigorous criteria for the stress resilience of the banking sector and the power of regulators in the minimization of systemic risks, national regulators are not always able to extend an adequate level of regulatory effectiveness to ensure financial stability. That is why the issue of "deriskization" of the banking sector remains open. Moreover, the process of shaping the post-crisis regulatory order showed that none of the countries and none of the national regulators alone could develop effective measures to overcome the aftermath of the crisis [Lane, 2012], ${ }^{20,}{ }^{21}$ which refutes the scepticism of a number of experts [Prasad, Rajan, 2009; Rodrik, 2000] regarding the failure of financial globalization

${ }^{17}$ The issue of systemically important financial institutions (SIFIs), including global systemically important banks (G-SIBs) (they are also known as "too big to fail") relates to the higher costs for the financial system and the economy at large in case of their insolvency and in the unexpected outcomes associated with their dysfunction, and broadly, with financial disintermediation.

${ }^{18}$ One should not underestimate the increase of banking costs in meeting the Basel III standards, which implies that a decrease of assets is associated with lower profitability which may be deficient in covering such costs.

${ }^{19}$ Without the latest aspects of the regulatory reform in December 2017 which complement some of the conceptual provisions of Basel III and aim at less-biased measurement of risk-weighted assets and capital adequacy standards [BIS, 2017].

${ }^{20}$ The extent of interconnectedness in global finance is impressive. Thus, about three quarters of the total losses of banks headquartered in the UK are in their overseas operations [Broadbent, 2012]; total losses of branches/subsidiaries of foreign banks operating in Ireland exceeded €22 billion, or $18 \%$ of Ireland's GDP for the period 2009-2011 [BIS, 2012b].

${ }^{21}$ According to a World Bank study, about $46 \%$ of top executives of credit institutions consider that contemporary banking regulation is unable to adequately minimize the risks of financial instability [World Bank Group, 2018]. 


\begin{tabular}{|c|c|c|c|c|c|c|c|c|c|c|c|c|c|c|c|c|c|}
\hline 总 & ভָ & $\underset{i}{\stackrel{p}{i}}$ & $\underset{i}{\stackrel{0}{i}}$ & $\stackrel{n}{\stackrel{n}{i}}$ & $\begin{array}{l}\hat{n} \\
i \\
+\end{array}$ & $\stackrel{2}{T}$ & \begin{tabular}{l}
0 \\
\multirow{2}{0}{} \\
0 \\
1
\end{tabular} & $\begin{array}{c}\stackrel{\partial}{+} \\
+ \\
+\end{array}$ & $\underset{\stackrel{+}{i}}{\overrightarrow{+}}$ & $\begin{array}{l}\underset{\sim}{\sim} \\
\stackrel{\oplus}{1}\end{array}$ & $\begin{array}{l}\stackrel{0}{\circ} \\
\stackrel{+}{+}\end{array}$ & $\underset{T}{\stackrel{T}{\top}}$ & $\stackrel{\Re}{\stackrel{\overbrace{}}{+}}$ & $\begin{array}{l}\infty \\
\stackrel{p}{j} \\
1\end{array}$ & $\begin{array}{l}\infty \\
i \\
i\end{array}$ & \begin{tabular}{l}
\multirow{2}{0}{} \\
oे
\end{tabular} & $\begin{array}{l}: \\
\dot{1}\end{array}$ \\
\hline 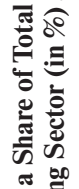 & 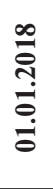 & $\stackrel{\varrho}{\varrho}$ & $\begin{array}{l}n \\
\infty \\
\infty\end{array}$ & ت & $\stackrel{\varrho}{\varrho}$ & $\underset{\stackrel{+}{+}}{\stackrel{\vec{f}}{ }}$ & 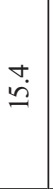 & 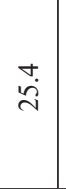 & $\stackrel{\circ}{\stackrel{\Xi}{=}}$ & 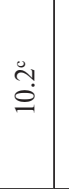 & तु & $\stackrel{\text { }}{\circ}$ & $\stackrel{\stackrel{m}{r}}{\circ}$ & $\stackrel{\ddot{v}}{\dot{m}}$ & $\dot{m}_{\infty}$ & $\hat{a}$ & 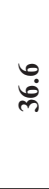 \\
\hline 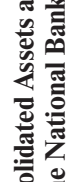 & 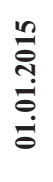 & $\exists$ & $\ddot{\sigma}$ & $\stackrel{m}{n}$ & $\begin{array}{l}\infty \\
\stackrel{0}{\varrho}\end{array}$ & $\begin{array}{l}0 \\
\dot{+}\end{array}$ & $\stackrel{m}{\sim}$ & $\begin{array}{l}\dot{0} \\
\dot{\sim}\end{array}$ & $\stackrel{+}{\ddot{g}}$ & $\stackrel{n}{\varrho}$ & $\stackrel{\infty}{\stackrel{\infty}{R}}$ & ๙a & $\begin{array}{l}\infty \\
\infty \\
\infty\end{array}$ & 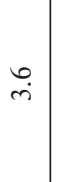 & $\stackrel{\circ}{\circ}$ & $\stackrel{9}{=}$ & $\vec{q}$ \\
\hline "ే & 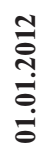 & $\stackrel{\sim}{\varrho}$ & $\stackrel{?}{\varrho}$ & $\begin{array}{l}\stackrel{t}{n} \\
\ddot{n}\end{array}$ & $\begin{array}{l}\stackrel{0}{a} \\
\text {. }\end{array}$ & $\begin{array}{l}n \\
\stackrel{\infty}{q}\end{array}$ & $\stackrel{n}{\sim}$ & $\hat{\grave{\lambda}}$ & $\stackrel{n}{\varrho}$ & $\stackrel{\infty}{\stackrel{\sim}{\sim}}$ & 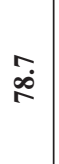 & $\stackrel{+}{\infty}$ & $\hat{b}$ & F & $\stackrel{\circ}{=}$ & $\stackrel{\vartheta}{\ddot{g}}$ & $\bar{f}$ \\
\hline & ত্যু & $\stackrel{\stackrel{7}{7}}{\underset{+}{+}}$ & $\underset{+}{\stackrel{+}{+}}$ & $\begin{array}{l}\stackrel{\sim}{+} \\
+ \\
+\end{array}$ & 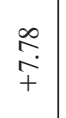 & $\underset{+}{\stackrel{\Phi}{+}}$ & $\begin{array}{l}\mathbb{U} \\
\dot{0} \\
0 \\
1\end{array}$ & 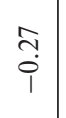 & $\frac{9}{\vec{\varphi}}$ & $\begin{array}{l}m \\
\stackrel{n}{1}\end{array}$ & $\begin{array}{l}r \\
00 \\
0 \\
1\end{array}$ & $\begin{array}{l}\stackrel{2}{0} \\
\stackrel{6}{+} \\
+\end{array}$ & $\begin{array}{l}\stackrel{\overrightarrow{\Upsilon े}}{+} \\
+\end{array}$ & $\begin{array}{l}\stackrel{2}{a} \\
\stackrel{\jmath}{+}\end{array}$ & 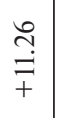 & î̀ & 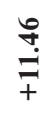 \\
\hline 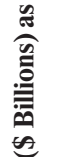 & 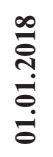 & $\underset{\sim}{\stackrel{m}{ }}$ & $\begin{array}{l}\stackrel{0}{\dot{\phi}} \\
\infty \\
\stackrel{m}{-}\end{array}$ & 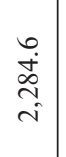 & $\begin{array}{l}m \\
o \\
0 \\
\stackrel{0}{-}\end{array}$ & 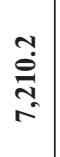 & $\begin{array}{c}\stackrel{c}{-} \\
\stackrel{n}{\sim} \\
\sim\end{array}$ & $\begin{array}{l}\infty \\
\overrightarrow{\vec{d}} \\
\tilde{\sim} \\
\vec{c}\end{array}$ & $\begin{array}{l}\stackrel{0}{0} \\
\stackrel{0}{0} \\
-\end{array}$ & $\begin{array}{l}\stackrel{\circ}{f} \\
\stackrel{0}{0} \\
\stackrel{0}{-}\end{array}$ & $\begin{array}{l}\overrightarrow{0} \\
\stackrel{\vec{\theta}}{0} \\
\vec{b}\end{array}$ & $\begin{array}{c}\dot{m} \\
\stackrel{m}{m} \\
\stackrel{m}{m}\end{array}$ & 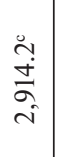 & 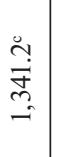 & $\begin{array}{l}\dot{0} \\
\ddot{a} \\
\text { mे } \\
\text { r. }\end{array}$ & 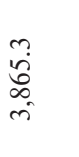 & $\begin{array}{l}\text { :̊. } \\
\text { in } \\
\text { in }\end{array}$ \\
\hline 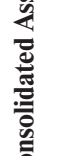 & 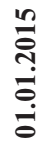 & 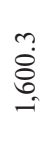 & $\begin{array}{l}\vec{\infty} \\
\stackrel{\infty}{\infty} \\
\stackrel{m}{-}\end{array}$ & 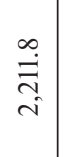 & $\begin{array}{l}0 \\
\infty \\
0 \\
n \\
\sim \\
-\end{array}$ & 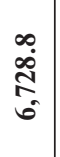 & 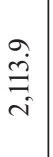 & $\begin{array}{l}\vec{f} \\
\text { bु } \\
i \\
i\end{array}$ & $\begin{array}{l}\infty \\
\stackrel{0}{0} \\
\stackrel{m}{-} \\
-\end{array}$ & $\begin{array}{c}\hat{\sim} \\
\vec{b} \\
- \\
-\end{array}$ & 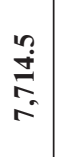 & $\begin{array}{l}\infty \\
\dot{j} \\
\hat{n} \\
\sim \\
\sim\end{array}$ & $\begin{array}{l}a \\
\infty \\
o \\
o \\
i \\
c\end{array}$ & $\underset{\sim}{\stackrel{\nabla}{\sigma}}$ & $\begin{array}{l}\text { ra } \\
\text { aे } \\
\text { i } \\
\text { in }\end{array}$ & 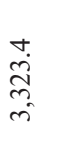 & $\begin{array}{l}\hat{\tilde{0}} \\
\stackrel{\Xi}{\Xi} \\
0\end{array}$ \\
\hline & 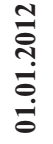 & 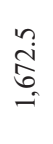 & 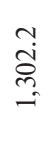 & $\begin{array}{l}m \\
\stackrel{\vec{n}}{=} \\
\underline{-}\end{array}$ & 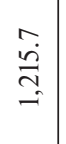 & 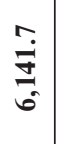 & $\begin{array}{l}\text { ma } \\
\stackrel{\circ}{+} \\
+ \\
i\end{array}$ & $\begin{array}{l}0 \\
\hat{n} \\
\tilde{n} \\
i \\
i\end{array}$ & $\begin{array}{l}\overrightarrow{0} \\
\stackrel{n}{n}\end{array}$ & $\begin{array}{l}\underset{i}{\sim} \\
\underset{\sim}{\sim} \\
\vec{i}\end{array}$ & 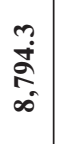 & 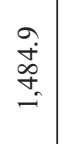 & $\begin{array}{l}\vec{a} \\
\dot{0} \\
\rightarrow \\
-1\end{array}$ & $\begin{array}{l}\stackrel{0}{0} \\
\stackrel{\mathbb{N}}{i}\end{array}$ & $\begin{array}{l}\stackrel{ }{\dot{\nabla}} \\
\text { ğ }\end{array}$ & $\begin{array}{l}\stackrel{0}{\dot{y}} \\
\stackrel{f}{\mathrm{i}} \\
\text { (n) }\end{array}$ & $\begin{array}{l}0 \\
0 \\
0 \\
0 \\
0 \\
\infty \\
\infty\end{array}$ \\
\hline 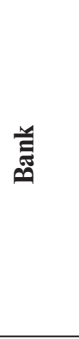 & & 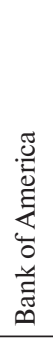 & 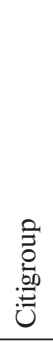 & 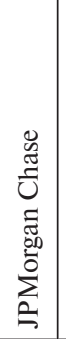 & 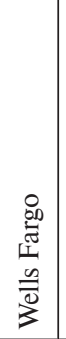 & 䓛 & 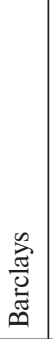 & $\begin{array}{l}U \\
\mathbb{0} \\
\widetilde{\Xi}\end{array}$ & 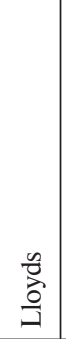 & 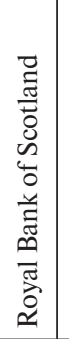 & 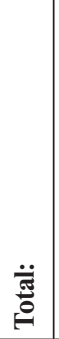 & 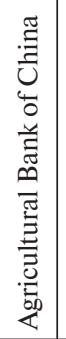 & 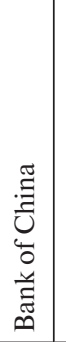 & 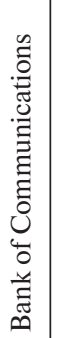 & 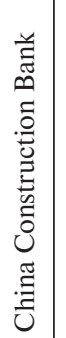 & 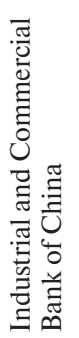 & 䔍 \\
\hline לे & & $\dot{\leftrightarrow}$ & & & & & $\breve{J}$ & & & & & 节 & & & & & \\
\hline
\end{tabular}




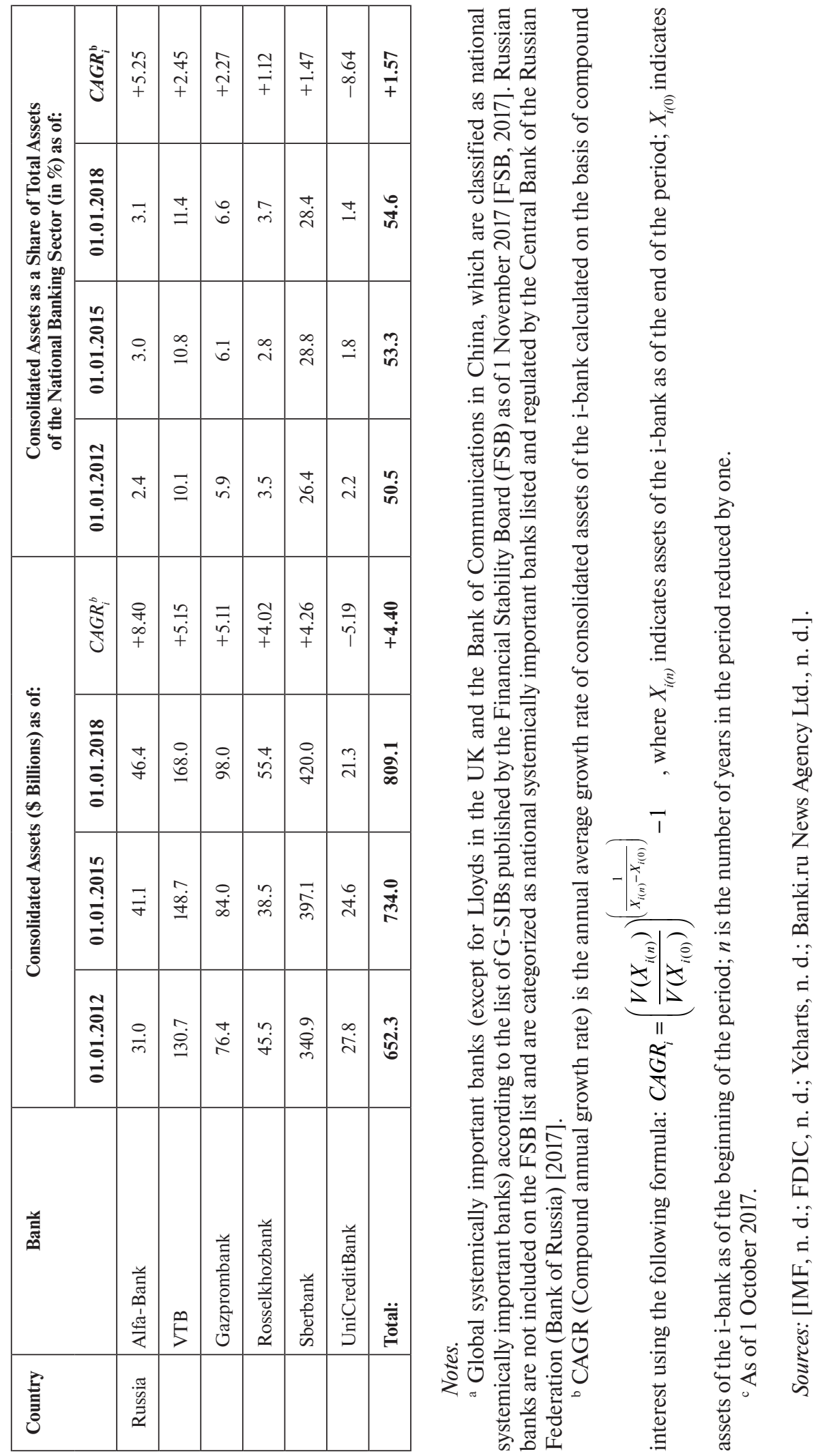


and regionalization, especially in developing countries. The joint effort of governments remains perhaps the only factor in developing the most effective regulatory policy amid the uncertainty of a macro level and risk-contributing environment, while having a shortage of reliable tools for early risk identification. Furthermore, given the increased interconnectedness of financial institutions in global financial markets, the crisis-management capacity of national governments has been significantly limited in recent years [Aikins, 2019; Jeong, Kim, 2010], ${ }^{22}$ and if they did act, the results were often insignificant due to the flawed understanding of the complex processes of international economic dynamics [Lane, 2012]. Therefore, it appears that the efficacy of national regulators to withstand crisis developments depends on the banks that they supervise: along with banks' internationalization, regulators become less capable of providing not only effective oversight, but also early identification of systemic risks and system-wide stress.

One should not delusively believe that the ideas of financial globalism determine regulatory policy at the national level, taking into account a number of drawbacks in the conceptual framework of the new regulatory standards (for example, when assessing capital adequacy) and vulnerabilities at the macro level (for example, being exposed to the volatility of global financial markets). Disproportions in the processes of financial globalization inevitably escalate information asymmetry and macro-financial imbalances, thereby increasing decision-making biases of national regulators. That is why the robustness of the regulatory and supervisory cycle is a time-varying factor of financial stability, and the effectiveness of regulation is measured by the lasting consistency and sustainability of financial intermediation. ${ }^{23}$

\section{The Regionalization and Supranationalization of Banking Regulation in the EAEU}

\section{The Background of Regulatory Regionalization}

The contemporary processes of financial globalization generate the processes of economic regionalism [Heathcote, Perri, 2004], which in turn are determined by the specifics of economic systems and different dynamics of national economic development [Hirata, Ayhan Kose, Otrok, 2013] thus resulting in regionalization in the financial area. However, the specifics of the post-crisis model of international banking regulation do not fully comply with the objective of the "deriskization" of the banking sector and inhibit the efforts to ensure financial stability. This urges national regulators to jointly search for factors underlying sustainable development, including the development of regional banking regulation mechanisms. The rise of regionalism in banking regulation is also driven by the fact that Basel III standards will not be accepted and applied globally (at least for the time being), on the one hand, and by the need of further internationalization of banking systems, on the other, which national regulators alone cannot put into action due to the growing risks of asymmetries in international banking regulation.

The issues of regionalization of regulation have not yet received proper attention in the extant economic literature. Nevertheless, the research findings indicate a decrease in procyclicality in countries participating in integration processes if the convergence of national banking

${ }^{22}$ However, the measures on stabilization taken by the governments of the crisis-affected Southeast Asian countries had a positive impact on key performance indicators of credit institutions (solvency, profitability, credit risk level) [Ding, Wu, Chang, 2013], although it can be assumed that it was systemically important banks with a higher level of internationalization that showed better performance, while their performance was also affected by the measures taken by governments of the countries in which they conducted their operations.

${ }^{23}$ This denotes the settlement of disproportions of banking activity with lower costs (not exceeding the level at which they noticeably impact the profitability of banks and their performance) and for a time horizon free from any disproportions in banking activity. 
regulation mechanisms and the integration of national banking sectors is one of the driving forces of integration [Kalemli-Ozcan, Papaioannou, Peydró, 2013]. ${ }^{24}$ At the same time, the effectiveness of financial integration is higher for capital-deficient countries which have access to new, relatively inexpensive sources of liquidity/funding ${ }^{25}$ [Hoxha, Kalemli-Ozcan, Vollrath, 2013]; however, it is believed that such a redistribution of resources is associated with the risk of regulatory arbitrage stemming from different regulatory regimes and, therefore, escalation of systemic risks.

\section{The European Union's Experience of Regionalized Banking Regulation}

The regionalization of regulatory policy is a response to unresolved issues associated with the protection of national financial systems from adverse externalities. This process becomes more apparent during the post-crisis recovery and is best illustrated by the experience of the European Union (EU), where a system of supranational institutions of banking regulation was created following the crisis (Table 2).

Table 2. Institutional Aspects of EU Banking Regulation

\begin{tabular}{|c|c|}
\hline The Institutions of Banking Regulation & $\begin{array}{l}\text { Area of Functional Responsibility } \\
\text { (Banking Regulation Segment) }\end{array}$ \\
\hline \multicolumn{2}{|l|}{ 1. The Institutes of Macroprudential Regulation } \\
\hline $\begin{array}{l}\text { 1.1. European Systemic Risk Board, ESRB } \\
\text { Established on } 16 \text { December } 2010 \\
\text { Location: Frankfurt am Main, Germany }\end{array}$ & $\begin{array}{l}\text { Macroprudential regulation of the EU financial } \\
\text { sector in order to minimize systemic risks and } \\
\text { ensure financial stability }\end{array}$ \\
\hline \multicolumn{2}{|l|}{ 2. The Institutes of Microprudential Regulation } \\
\hline $\begin{array}{l}\text { 2.1. European Banking Authority, EBA } \\
\text { Established on } 1 \text { January } 2011 \\
\text { Predecessor: Committee of European Banking Supervisors } \\
\text { Established on } 5 \text { November } 2003 \\
\text { Location: London, UK }\end{array}$ & $\begin{array}{l}\text { Stress testing of European banks in order } \\
\text { to identify weaknesses in their capital structure, } \\
\text { as well as to increase their transparency }\end{array}$ \\
\hline $\begin{array}{l}\text { 2.2. European Securities and Markets Authority, ESMA } \\
\text { Established on } 1 \text { January } 2011 \\
\text { Predecessor: Committee of European Securities Regulators } \\
\text { Established on } 6 \text { June } 2001 \\
\text { Location: Paris, France }\end{array}$ & $\begin{array}{l}\text { Development of legislation and regulation } \\
\text { of financial markets in the EU; coordination } \\
\text { of the activities of the national financial market } \\
\text { regulators; protection of investors' rights }\end{array}$ \\
\hline $\begin{array}{l}\text { 2.3. European Insurance and Occupational Pensions Authority, EIOPA } \\
\text { Established on } 1 \text { January } 2011 \\
\text { Predecessor: Committee of European Insurance and Occupational } \\
\text { Pensions Supervisors } \\
\text { Established on } 5 \text { November } 2003 \\
\text { Location: Frankfurt am Main, Germany }\end{array}$ & $\begin{array}{l}\text { Protection of the rights of policyholders } \\
\text { and pension schemes participants; issues of } \\
\text { corporate governance, audit and financial } \\
\text { reporting of insurance and reinsurance } \\
\text { companies and insurance intermediaries }\end{array}$ \\
\hline
\end{tabular}

${ }^{24}$ According to the results of the same study, $50 \%$ of integration in banking regulation entails a decrease in synchronization of economic cycles by $0.2 \%$ [Kalemli-Ozcan, Papaioannou, Peydró, 2010, p. 9]. At the same time, the issue of the quantitative assessment of integration proposed by the authors remains vague, taking into account the multiple factors affecting both the integration process along with its results and importance for financial stability.

${ }^{25}$ Compared to the sources of funding/liquidity in the national financial market. 


\begin{tabular}{|c|c|}
\hline The Institutions of Banking Regulation & $\begin{array}{l}\text { Area of Functional Responsibility } \\
\text { (Banking Regulation Segment) }\end{array}$ \\
\hline $\begin{array}{l}\text { 2.4. Single Resolution Board, SRB } \\
\text { Established on } 1 \text { January } 2016 \\
\text { Location: Brussels, Belgium }\end{array}$ & $\begin{array}{l}\text { Resolution of insolvency and issues of } \\
\text { bankruptcy of credit institutions in the eurozone } \\
\text { countries; assessment of perspectives for } \\
\text { settlement and the sufficiency of funds for these } \\
\text { purposes }\end{array}$ \\
\hline $\begin{array}{l}\text { 2.5. European Central Bank, ECB } \\
\text { Established on } 1 \text { June } 1998 \\
\text { Predecessor: European Monetary Institute, EMI } \\
\text { Location: Frankfurt am Main, Germany }\end{array}$ & $\begin{array}{l}\text { Supranational regulation and supervision of } \\
\text { banks in the eurozone countries that meet the } \\
\text { criteria of systemic importance for the EU } \\
\text { (since } 4 \text { November 2014) }\end{array}$ \\
\hline
\end{tabular}

Sources: [EC, n. d.; ESRB, n. d.; EBA, n. d.; ESMA, n. d.; EIOPA, n. d.; SRB, n. d.; ECB, n. d.].

From a functional perspective, the EU's regulatory institutions are based on three interrelated platforms of integration - the Single Supervisory Mechanism (SSM), the Single Resolution Mechanism (SRM) and single deposit insurance principles. The development of institutional infrastructure contributes not only to filling the void in the regulation of international capital flow [Boyer, Kempf, 2017], but also to ensuring a balance of interests between different segments of the financial market [Yue, Luo, Ingram, 2013], which is critical in the context of banking sector fragmentation.

\section{The Institutional Structure of EAEU Banking Regulation: Specifics, Inconsistencies and Risks}

The EAEU integration process requires more efficient trade and economic cooperation amid the lengthy recovery of the world economy following the crisis and the lack of handy recipes for financial stability. Although Eurasian integration so far involves the non-financial sector only, the integration of the financial realm, including the mechanisms of banking regulation and prudential banking supervision, is critically important given the risks of inconsistency in integration and their lasting effects. ${ }^{26}$

At the same time, use of the EU's experience in regulatory regionalization can reduce costs but does not guarantee the effectiveness of regionalization in the EAEU and its implementation. The problem is not only related to the significant imbalances of the macro level parameters and the lower potential of Eurasian financial institutions, nor only to the different approaches to macro-financial management policy which can become a source of additional risk for integration processes [Shirov, Gusev, 2013, p. 15] thereby escalating inconsistencies of integration. The problem is also in the lack of a mutually agreed concept for a regional regulatory framework and understanding of the extent of the internationalization of the regional banking regulation mechanism. Finally, it remains unclear how the inconsistencies could be resolved should the concept and organizational format of the future EAEU supranational financial markets authority, stipulated by the Treaty on the Eurasian Economic Union of 29 May 2014 [EAEU, 2014] not comply with the interests of national regulators.

${ }^{26}$ The Treaty on the Eurasian Economic Union [EAEU, 2014] already stipulates harmonization of banking regulation and supervision in accordance with the principles of effective banking supervision of the BCBS [EAEU, 2014, Annex 17, Clause 22]; approaches to risk management in EAEU financial markets in accordance with international standards [Ibid., Art. 70, Clause 1.4]; prudential requirements for banking activities [Ibid., Art. 70, Clause 1.5]; and procedures for supervision of the activities of financial market participants [Ibid., Art. 70, Clause 1.6]. 
The institutional basis of the EAEU regional regulatory mechanism will be an integral part of the EAEU regulatory system. In fact, the institutional basis has a critical meaning in the self-development of economic systems, thus minimizing the risks of bureaucracy and administration [Grigor'ev, 2013, p. 51]. To date, there is only a broad outline of the future EAEU regulatory mechanism, the design of which, in accordance with the treaty on the EAEU, suggests the concentration of all regulatory functions in a single institution. It can be assumed that the choice of design of a supranational regulator is not accidental: it is a key to effective coordination among regulators of the EAEU states according to the matrix principle ${ }^{27}$ (Table 3).

Table 3. The Institutional Structure of Banking Regulation in the EAEU

\begin{tabular}{|l|l|l|}
\hline \multicolumn{1}{|c|}{ EAEU State } & $\begin{array}{c}\text { Authorized Institute for } \\
\text { Banking Regulation and } \\
\text { Supervision }\end{array}$ & \multicolumn{1}{c|}{ Notes } \\
\hline $\begin{array}{l}\text { Republic } \\
\text { of Armenia }\end{array}$ & $\begin{array}{l}\text { Central Bank of the } \\
\text { Republic of Armenia }\end{array}$ & $\begin{array}{l}\text { The single regulator of the financial market since its foundation in } \\
\text { 1993. }\end{array}$ \\
\hline $\begin{array}{l}\text { Republic } \\
\text { of Belarus }\end{array}$ & $\begin{array}{l}\text { National Bank of the } \\
\text { Republic of Belarus }\end{array}$ & $\begin{array}{l}\text { A banking sector regulator since its inception in 1992. } \\
\text { The securities market is regulated by the Securities Department of the } \\
\text { Ministry of Finance of the Republic of Belarus (as a legal entity). } \\
\text { Insurance and audit activities are regulated by the Ministry of Finance } \\
\text { of the Republic of Belarus. }\end{array}$ \\
\hline $\begin{array}{l}\text { Republic } \\
\text { of Kazakhstan }\end{array}$ & $\begin{array}{l}\text { National Bank of the } \\
\text { Republic of Kazakhstan }\end{array}$ & $\begin{array}{l}\text { A single regulator of the financial market from its foundation in 1991 } \\
\text { until 2004, after which the regulatory responsibilities were transferred } \\
\text { to the Agency of the Republic of Kazakhstan on Regulation and } \\
\text { Supervision of Financial Market and Financial Organizations. } \\
\text { The function of a single financial market regulator (mega-regulator) } \\
\text { was restored after the abolition of the above agency (Decree of the } \\
\text { President of the Republic of Kazakhstan No 25 of 12 April 2011). }\end{array}$ \\
\hline Kyrgyz Republic & $\begin{array}{l}\text { National Bank of the } \\
\text { Kyrgyz Republic }\end{array}$ & $\begin{array}{l}\text { A single financial market regulator from its inception in 1991 until } \\
\text { 2005, after which the functions of financial market supervision }{ }^{1} \text { were } \\
\text { transferred to the State Service of Regulation and Supervision of the } \\
\text { Financial Market at the Government of the Kyrgyz Republic (State } \\
\text { Financial Supervision Agency). }\end{array}$ \\
\hline $\begin{array}{l}\text { Russian } \\
\text { Federation }\end{array}$ & $\begin{array}{l}\text { Central Bank of the Russian } \\
\text { Federation (Bank of Russia) }\end{array}$ & $\begin{array}{l}\text { A banking sector regulator since its inception in 1990. } \\
\text { A single financial market regulator (mega-regulator) since September } \\
\text { 2013 after the abolition of the Federal Service for Financial Markets of } \\
\text { the Russian Federation and the transfer of responsibility to the Central } \\
\text { Bank of the Russian Federation (Decree of the President of the Russian } \\
\text { Federation No 645 of 25 July 2013). }\end{array}$ \\
\hline
\end{tabular}

1 Supervision of the securities market and the activities of non-bank financial institutions.

${ }^{2}$ Before its abolition, the oversight was extended only to non-bank financial institutions.

Source: official sites of the central (national) banks and financial markets regulators of the EAEU member states. [Central Bank of the Republic of Armenia, n. d.; National Bank of the Republic of Belarus, n. d.; Ministry of Finance of the Republic of Belarus, n. d.; National Bank of the Republic of Kazakhstan, n. d.; National Bank of the Kyrgyz Republic, n. d.; Service for Regulation and Supervision of the Financial Market Under the Government of the Kyrgyz Republic (State Financial Supervision Agency), n. d.; Central Bank of the Russian Federation (Bank of Russia), n. d.].

It appears that the principle of regulatory monocentrism in the EAEU, where regulatory responsibilities are borne by the central banks, is so far the optimal approach to the protection

${ }^{27}$ In the Republic of Belarus and in the Kyrgyz Republic, functions of financial regulation are distributed between the central bank and a specialized institution; however, regulation of the banking sector is exclusively assigned to the central bank, which does not contradict the matrix-based principles of coordination. 
of regional financial markets from adverse externalities, at least until the processes of economic integration achieve organizational and managerial maturity. If the central banks of the EAEU states coordinate the development of the regional regulatory mechanism, this will support consistency in regulatory decision-making and reduce the risks of fragmentation and information asymmetry in the EAEU financial markets.

Despite the identical institutional structure of EAEU banking regulations, significant differences in economic aspects of regulation may significantly slow down the delegation of authority from the national to the supranational leve ${ }^{28}$ and, as such, may delay the operationalization of the Eurasian financial markets authority. The problem in the differences of regulatory regimes could be resolved if the principles and standards of EAEU-wide regulation are acceptable to all EAEU states within the framework of the single regional regulatory mechanism - the so-called mini-Basel III. ${ }^{29}$ The mini-Basel III framework implies the future EAEU regional banking regulation mechanism, including its supranational institutional architecture and standards of prudential banking supervision based on the core principles of effective banking supervision and Basel III, mutually agreed by the EAEU states. In other words, the mini-Basel III concept suggests synchronization of national banking regulation regimes in the context of the objectives of EAEU integration and the development of a single EAEU financial market.

In terms of the coordination of regulatory convergence, the future supranational regulator to a certain extent simplifies the roadmap toward regulatory supranationalization. But will this secure the stress resilience of banks and banking systems to the extent of their ability to decisively sustain integration processes as creditors of the economy? This question logically leads to a number of other questions, the answers to which should clarify the extent to which the convergence of national regulatory mechanisms and regulatory supranationalization would be a necessary and sufficient condition for launching a full-fledged banking regulation mechanism in the EAEU:

- Will the trilemma between capabilities, demand and the potential of regulatory supranationalization in the EAEU be resolved?

- Will the single-institutional structure of supranational regulation be able to ensure the stress resilience of the EAEU national banking sectors and financial stability?

- Will the single-institutional structure of supranational regulation be able to ensure the effectiveness of measures for the early identification of systemic risks?

- What should be the extent, criteria and timeframe for delegation of authority from the national to a supranational level so that mini-Basel III becomes the foundational framework for the convergence of national regulatory regimes?

- Will supranational regulatory policy ensure equal access of banks to the financial markets of the EAEU states and, if so, will there be an EAEU-wide level playing field given the incompatibility of the national financial sectors?

- How effectively will the possible inconsistencies of the national banking regulation mechanisms be resolved, including during the process of supranationalization?

- Will the supranationalization of regulation ensure that banks will not be affected by crises and, if so, will synergistic effects of the regional regulatory mechanism exceed the costs of ensuring the stress resilience of banks?

- Will the costs associated with the supranational regulatory mechanism be commensurate with the synergistic effect of regionalization?

${ }^{28}$ This refers to the uneven readiness of the EAEU states to delegate regulatory power to the supranational authority, which may become one of the main setbacks of Eurasian integration. It is noteworthy that financial stability in the EAEU depends on the extent and relevance of delegated power, as well as on the extent of independence of the regulatory institutions [Hagendorff, 2013].

${ }^{29}$ For more details of the mini-Basel III concept see Dzhagityan [2015, 2017b]. 
- Will the matrix principle of interrelationship enhance the effectiveness of coordination between the national and supranational levels of regulation?

- Will the matrix principle of interrelationship enhance the adaptation capabilities of banks as a part of the transition to the principles and standards of mini-Basel III?

- Will regulatory supranationalization diminish interaction between banks and national regulators?

The issues related to the institutionalization of banking regulation in the EAEU are linked to the issue of whether the future supranational regulator will be a fully functional authority: will it be effective as an institution, taking into account a single-institution-based concentration of the economic aspects of regulation (for example, compared to regulatory responsibilities of the EU's regulatory institutions (see Table 2)) and the coordination of the regulatory convergence process? Although supranationalization seems to be relatively simple, one should consider the hidden, currently unknown, risks of convergence which ultimately may outweigh the advantages of a single-institutional regulatory structure with excessive centralization of supervisory power. The alternative scenarios for the EAEU regulatory mechanism can be called upon to address the needs of better regulatory logistics, the patterns of coordination between national regulators and convergence of national supervision regimes, the transparency of the regulatory mechanism, and the independence of regulatory authorities. Table 4 lays out the scenarios of regulatory convergence in the context of benefits and risks.

A matrix-based approach to the convergence of national regulatory mechanisms and single-institution-based regulatory supranationalization (Scenario 1) suggests instant organizational, economic and methodological interaction between national and supranational levels and, as such, can effectively manage systemic risks compared to Scenarios 2 and 3. However, due to the "under-internationalization" of the national banking sectors (except Russia), institutional asymmetry and fragmentation of national financial sectors, as well as their focus mainly on the domestic financial markets, national regulators may be reluctant to delegate their power to the supranational level [Howarth, Quaglia, 2016], driven by their expectations of disproportions and setbacks in regional economic cooperation. The situation is complicated by the weak representation of EAEU states' credit institutions in each other's banking sectors which primarily devalues their potential as drivers of integration and creates risks of an ambivalent regulatory convergence..$^{30}$ Additionally, excessive centralization of responsibilities within a single regulator can seriously weaken efforts to overcome the asymmetries associated with differences in size, structure, competitiveness, systemic stress and stress resilience of the national banking sectors. It is expected that the criteria and the extent of delegation of regulatory power will be the issue of major concern during the process of mutual approval, and this may impede the convergence of national regulatory mechanisms in the mini-Basel III framework, ultimately causing slack and maladjustment in the EAEU integration processes. This dilemma could find its solution in an EAEU-level authority on regional financial stability, which would ensure a balanced approach to national regulators and the process of supranationalization; however, such an authority is beyond the framework of the treaty on the EAEU and therefore does not fit into the institutional structure stipulated by Scenario 1.

The dominance of commercial banks in the EAEU banking sectors (compared with other categories of financial institutions, for example, credit cooperatives) to a certain extent clears the perspectives of intergovernmental consensus on banking supervision standards [Corbet,

\footnotetext{
${ }^{30}$ Although the activities of credit institutions in the financial markets of other countries yield mutual benefits, and given the inevitability of this process in financial and economic integration, the redistribution of market share between local and foreign-funded banks in terms of loans may provoke fragmentation and volatility in financial markets; however, these risks increase in countries with open economies of smaller sizes [Agénor, 2003].
} 


\begin{tabular}{|c|c|c|c|c|c|}
\hline 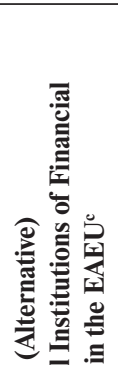 & $\frac{n}{\underline{n}}$ & 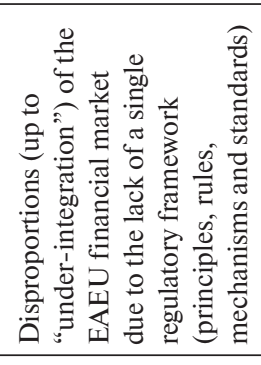 & 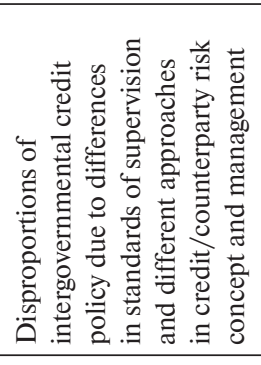 & 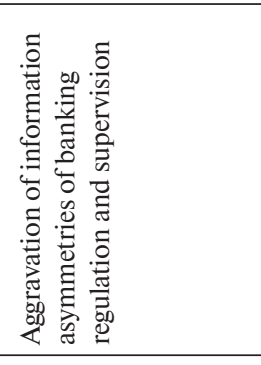 & 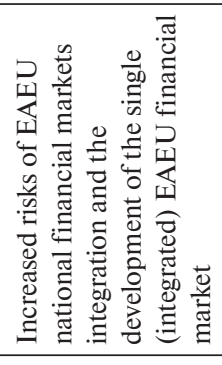 \\
\hline 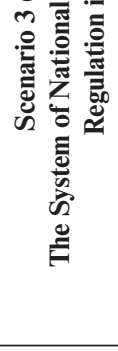 & 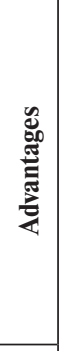 & 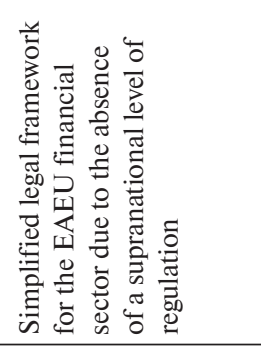 & 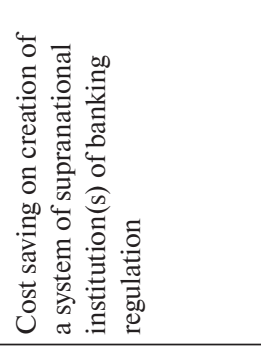 & 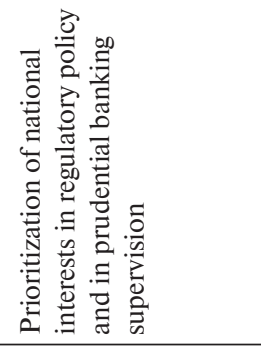 & 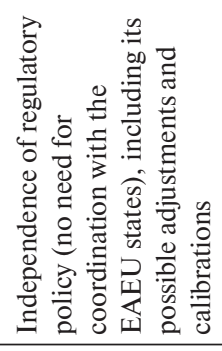 \\
\hline 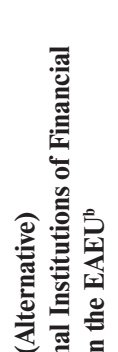 & $\frac{n}{\tilde{n}}$ & 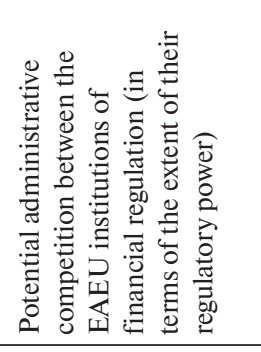 & 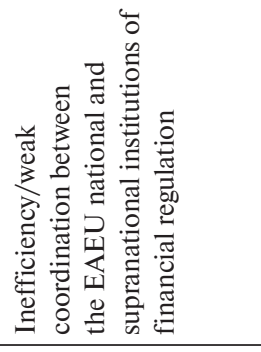 & 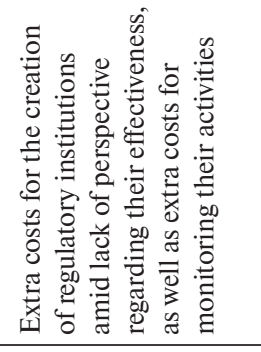 & 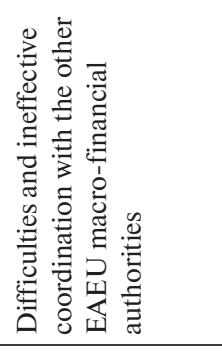 \\
\hline 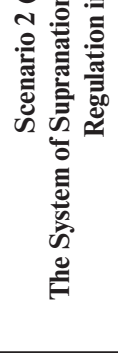 & 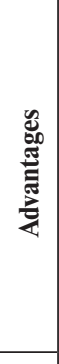 & 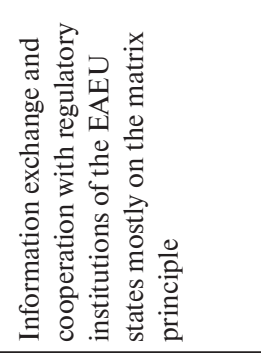 & 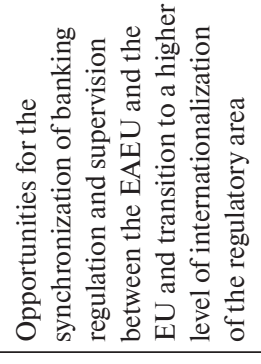 & 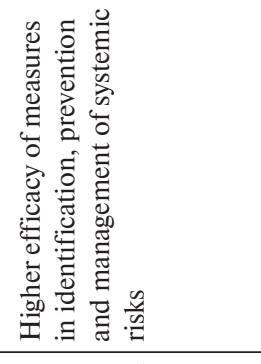 & 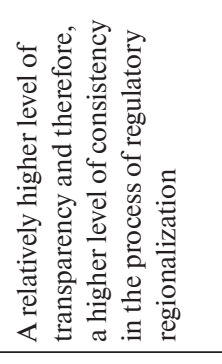 \\
\hline 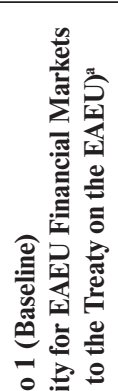 & $\frac{\tilde{y}}{\underline{a}}$ & 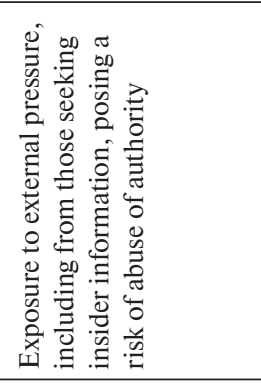 & 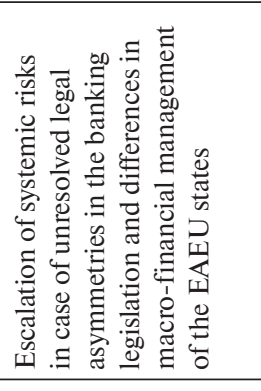 & 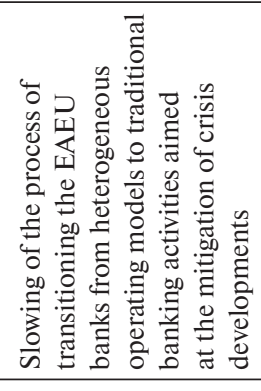 & 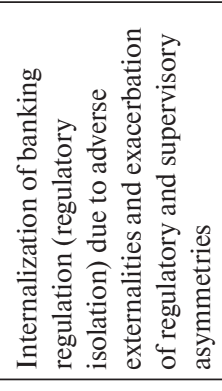 \\
\hline 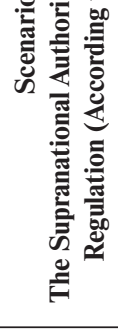 & 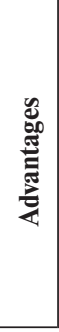 & 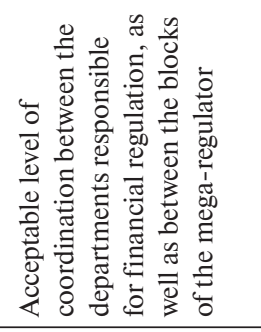 & 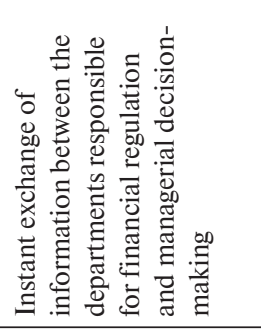 & 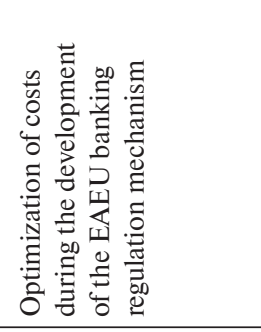 & 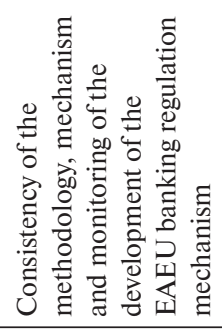 \\
\hline
\end{tabular}




\begin{tabular}{|c|c|c|c|c|}
\hline 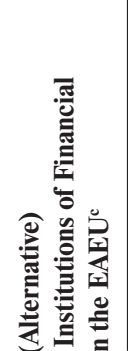 & $\frac{\tilde{y}}{\underline{\underline{n}}}$ & 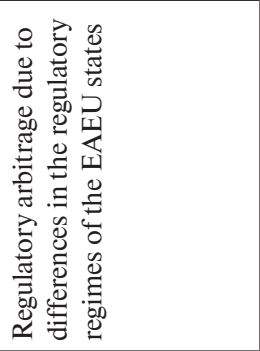 & 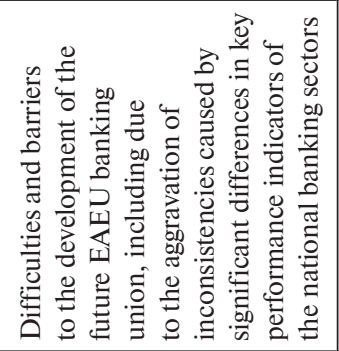 & 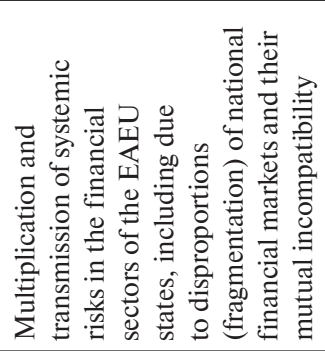 \\
\hline 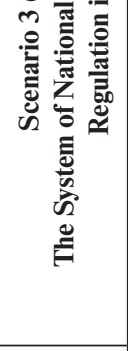 & 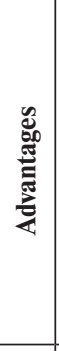 & 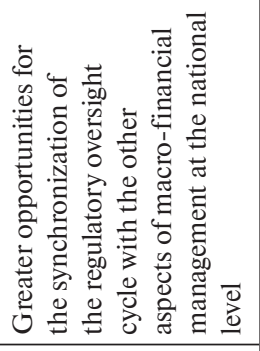 & & \\
\hline 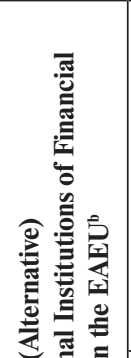 & $\frac{n}{\frac{n}{n}}$ & 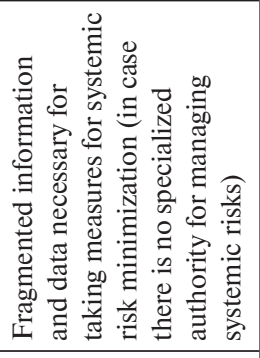 & 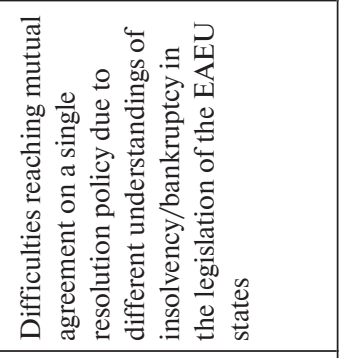 & \\
\hline 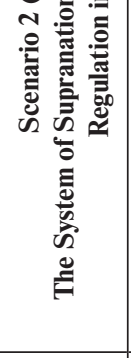 & 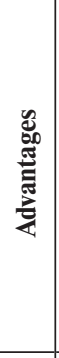 & 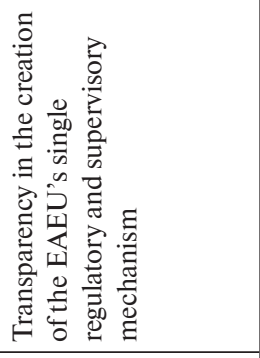 & 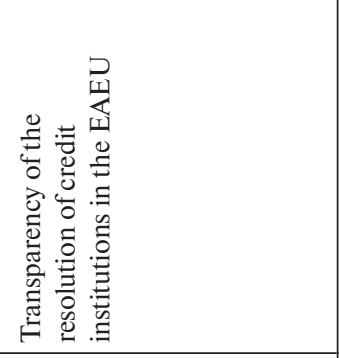 & 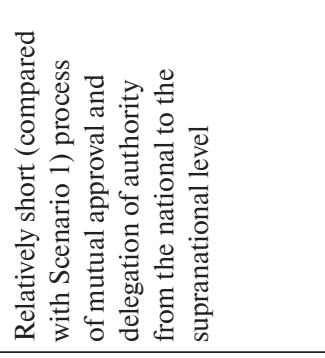 \\
\hline 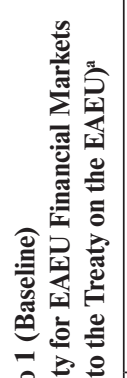 & $\frac{\frac{\tilde{u}}{\underline{a}}}{\underline{\underline{a}}}$ & 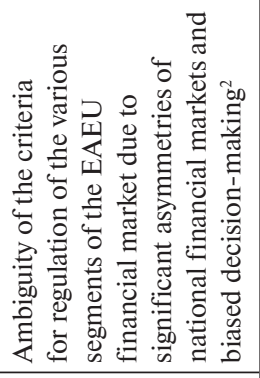 & 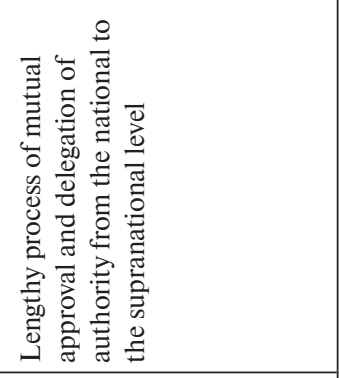 & 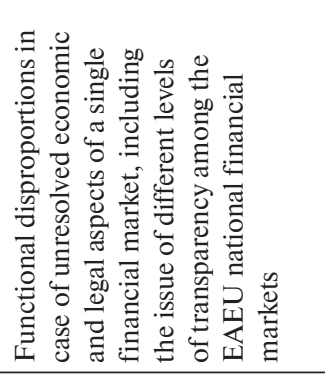 \\
\hline 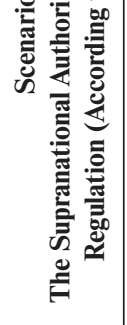 & 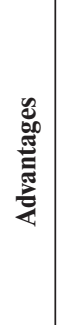 & 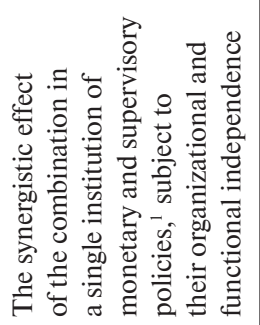 & 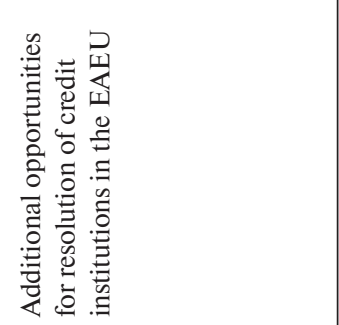 & 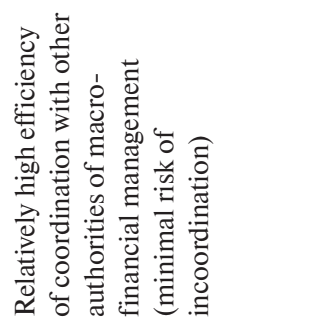 \\
\hline
\end{tabular}



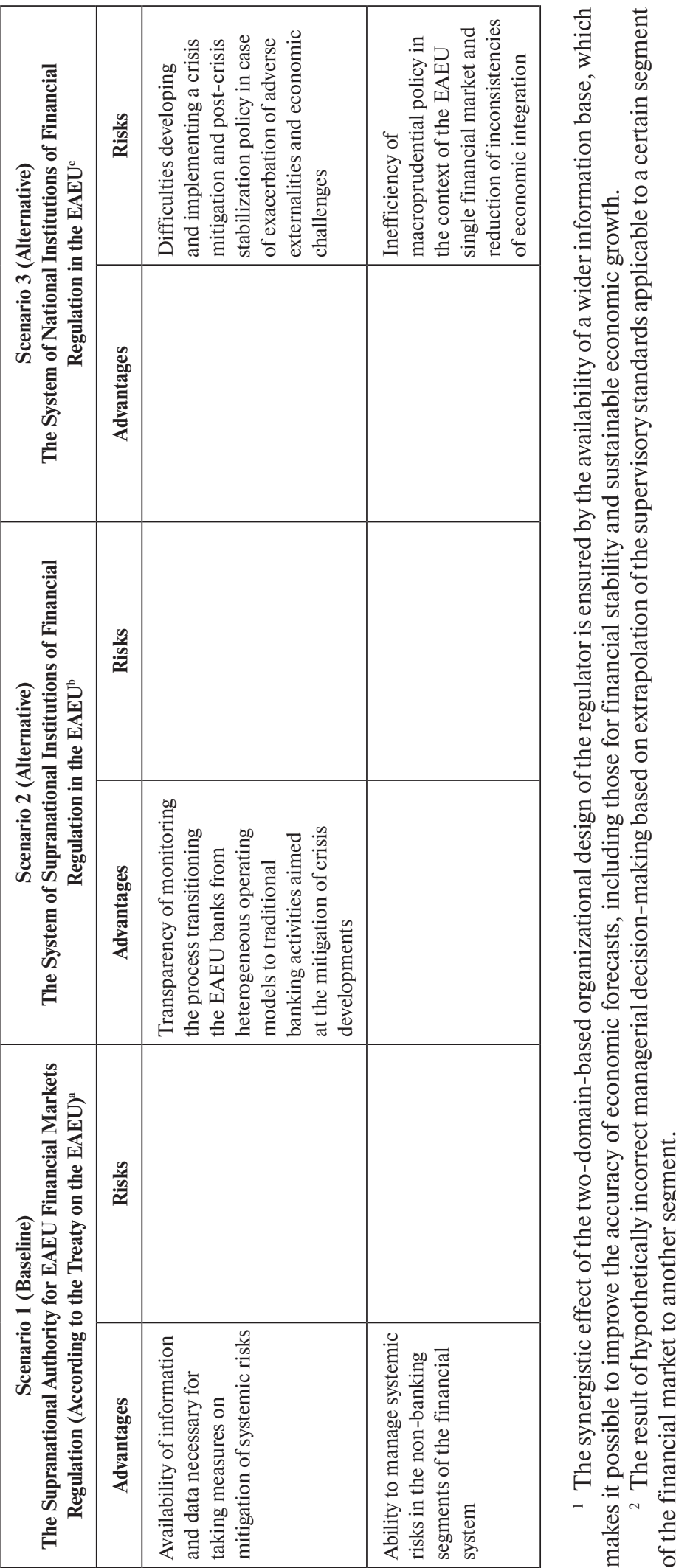

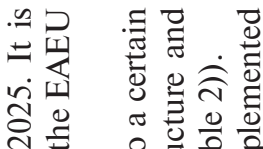

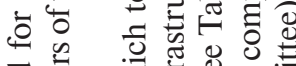

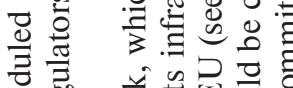

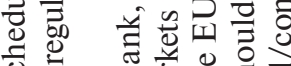

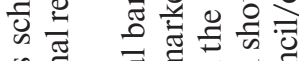

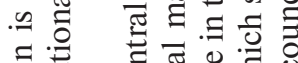

윯

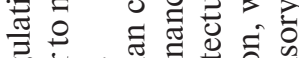

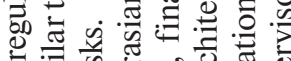

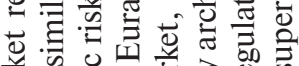

屯ै.

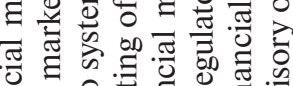

总

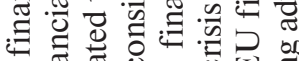

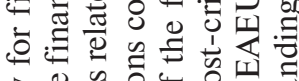

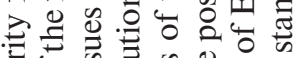

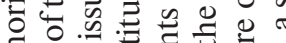

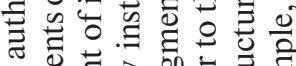

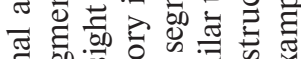

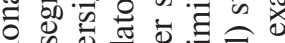

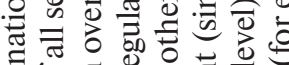
준

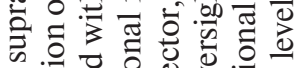

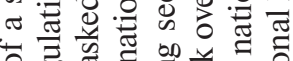

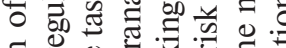

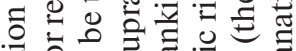

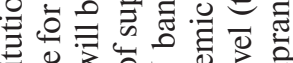

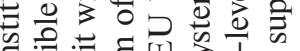

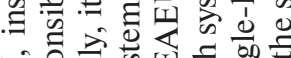

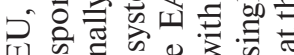
पy

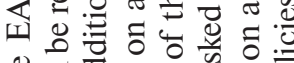

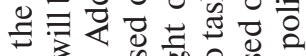

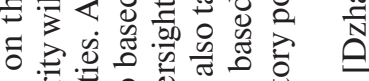
空完: 을

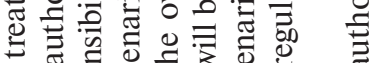

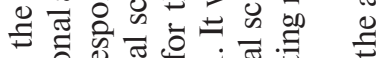

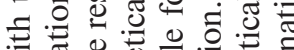

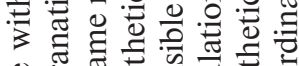
\&

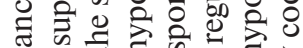

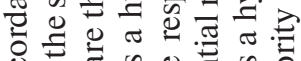

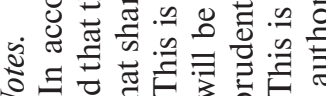

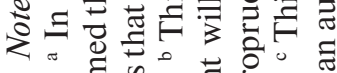

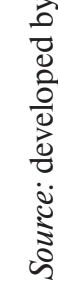


Larkin, 2017], which is a positive factor in all three scenarios of regulatory regionalization. At the same time, this sort of a simple micro-level landscape will require a simplified, least-cost approach to regionalization (Scenarios 1 and 3). However, possible sophistication of financial markets and diversification of financial instruments may require the inclusion in Scenarios 1 and 2 of a supranational regulatory authority that would be responsible for coordination of the regulatory convergence process, and the choice between these two scenarios will depend on the level of risks in the financial area and how it is protected from threats to financial stability.

Scenario 2, associated with regulatory decentralization, could become the basis of a regional regulatory mechanism in case of insurmountable differences in the organizational and functional structure of the national banking sectors and the infrastructure of the national financial markets. The multi-institutional regulatory mechanism implies a higher level of efficiency in minimization of systemic risks and achievement of financial stability, drawing on the EU experience (see Table 2). On the other hand, the efficiency of this scenario will depend on the efficiency of coordination among supranational regulatory institutions and between them and the central banks of the EAEU states, as well as whether mini-Basel III will be the core in supporting the economic aspects of this scenario. The similarity with the institutional structure of EU banking regulation can open up new opportunities for the exchange of information, which in turn will contribute to the outcome of an EAEU-wide regulatory mechanism, foster the growth of confidence in the EAEU supranational regulatory system and benefit international regulatory reform with expanded internationalization.

Unlike Scenarios 1 and 2, Scenario 3 does not involve supranational regulatory institutions. Amid regulatory "simplification," the soundness of regionalization will be determined by consensus among the EAEU states on issues that are less concerned with regulatory policy and more concerned with the convergence of supervisory standards which can secure a level playing field and enhance the role of financial intermediation in integration processes. However, this approach does not address a number of issues that may affect not only the effectiveness of the regulatory regionalization process, but also the consistency of the future design of EAEU banking regulation, including issues of information exchange among national regulators for timely and coordinated decision-making (Scenario 1); the issues of identification of systemic risks (Scenario 2); the perspectives of internationalization of the regulatory mechanism (Scenarios 1 and 2); and the degree of independence of national regulators. ${ }^{31}$ Also, the absence of supranational regulatory mechanisms will entail additional risks in the integration process [Zuev, 2011, p. 37]. Obviously, in the absence of a supranational coordinating authority, Scenario 3 may lack the principles of mini-Basel III, thus creating the risk of non-achievement of regulatory consensus among the EAEU states.

\section{Some Conclusions}

Without questioning the institutional basis of EAEU financial market regulation stipulated by the treaty on the EAEU, it should be noted that the process of regionalization of banking regulation most probably will be associated with unmanageable (systematic) risks in the Eurasian financial markets. Given the higher level of fragmentation of EAEU financial markets and the significant differences in national banking regulation regimes, these risks may further escalate systemic risks thus challenging the objective of financial stability.

In volatile macro level dynamics, the institutional landscape of EAEU banking regulation should become one of the fundamental determinants of Eurasian economic integration. How-

${ }^{31}$ In accordance with the statutory documents, central banks of the EAEU states report to the national parliaments, while national banks report to their heads of state. 
ever, significant differences in macroeconomic and macro-financial management in the EAEU states, including regulatory regimes, are a source of inconsistencies of regulatory convergence, which to a certain extent diminishes the perspectives of regulatory regionalization. The experience of the system of regulatory institutions in the EU urges consideration of alternative ways to shape the institutional framework of EAEU banking regulation with the mutually agreed principles of institutional structure necessary to meet the regional regulatory priorities.

The choice of the best integration scenario for institutional supranationalization of banking regulation is limited by the unique model of EAEU integration and the underlying regulatory paradigm due to a number of differences in scope, structure, key parameters and dynamics of the macro level of the countries involved in integration, on the one hand, and the lack of a holistic concept of the regional regulatory mechanism and the future Eurasian banking union, on the other. However, the limited selection of criteria can be overcome by considering the institutional regionalization of regulation based on consolidated criteria and schemes that are the foundation of any integration process.

The choice of integration scenario should be determined by strategic benchmarks of integration that in turn should be driven by the extent of financial intermediation associated with the needs of integration processes, while the rationale of the choice should be predicated upon the development of an integrated ecosystem of regional banking regulation, the capability of which should not depend on a possible transformation of the EAEU realm.

The choice of integration scenario should depend on the ability of national regulators to find mutually agreed economic aspects of regulatory convergence, including the mini-Basel III concept and implementation of its standards. The synergistic effect of Eurasian regulatory institutionalization will largely depend on the ability of mini-Basel III to resolve the current regulatory trilemma - the convergence of national regulatory mechanisms, retention of the interests of national regulators and ensuring financial stability.

The choice of integration scenario should be based on common principles for the effective management of the volatile economic environment, a flexible and crisis-protective regulatory model and a consistent methodological framework that will solidify systemic stability in the EAEU financial area aimed at achieving the ultimate objective of regionalization - an EAEU banking union. It is likely that involvement of banks in the integration process will be ensured by flexible standards of prudential banking supervision within the mini-Basel III framework, which will comply with the interests of national regulators and the objectives of regulatory regionalization. In this context, possible calibrations of regulatory policy during the regionalization process will set to elevate the role of banks to a principally new level, ensuring the effectiveness of EAEU integration together with sustainable economic growth and financial stability.

\section{References}

Agénor P.-R. (2003) Benefits and Costs of International Financial Integration: Theory and Facts. The World Economy, vol. 26, no 8, pp. 1089-118.

Aikins S. (2009) Global Financial Crisis and Government Intervention: A Case for Effective Regulatory Governance. International Public Management Review, vol. 10, no 2, pp. 23-43. Available at: https://ssrn.com/ abstract $=2689183$ (accessed 27 February 2018).

Bank for International Settlements (BIS) (2012a) Core Principles for Effective Banking Supervision. Basel Committee on Banking Supervision. Available at: https://www.bis.org/publ/bcbs230.pdf (accessed 31 May 2019).

Bank for International Settlements (BIS) (2012b) Household Indebtedness: Context, Consequence \& Correction. Address by Mr. Patrick Honohan, Governor of the Central Bank of Ireland, to the Limerick Law Society, 
University of Limerick, Limerick, 14 March. Available at: http://www.bis.org/review/r120315b.pdf?frames=0 (accessed 27 February 2018).

Bank for International Settlements (BIS) (2017) Finalising Basel III. Basel Committee on Banking Supervision (BCBS). Available at: https://www.bis.org/bcbs/publ/d424_inbrief.pdf (accessed 20 March 2018).

Bank for International Settlements (BIS) (2018) Keynote Speech by Stefan Ingves, Chairman, Basel Committee on Banking Supervision at the Institute for Law and Finance Conference, Goethe University, Frankfurt, 29 January. Available at: https://www.bis.org/speeches/sp180129.pdf (accessed 31 May 2019).

Banki.ru News Agency Ltd. (n. d.) Bank Ratings. Available at: https://www.banki.ru/banks/ratings/ (accessed 1 June 2019) (in Russian).

Boyer P.C., Kempf H. (2017) Regulatory Arbitrage and the Efficiency of Banking Regulation. Journal of Financial Intermediation. Available at: https://doi.org/10.1016/j.jfi.2017.09.002 (accessed 31 May 2019).

Central Bank of the Republic of Armenia (n. d.) Legal Acts. Available at: https://www.cba.am/en/sitepages/ lalaws.aspx (accessed 31 May 2019).

Central Bank of the Russian Federation (Bank of Russia) (n. d.) Official Site of the Central Bank of the Russian Federation (Bank of Russia). Available at: https://www.cbr.ru/eng/ (accessed 31 May 2019).

Central Bank of the Russian Federation (Bank of Russia) (2017) Ob utverzhdenii perechnja sistemno znachimyh kreditnyh organizacij [On Approval of the List of Systemically Important Credit Organizations]. Press-Sluzhba, 13 sentjabrja [Press Service, 13 September]. Available at: http://www.cbr.ru/press/ PR/?file=13092017_194655ik2017-09-13t19_46_25.htm (accessed 17 February 2018) (in Russian).

Corbet S., Larkin C. (2017) Has the Uniformity of Banking Regulation within the European Union Restricted Rather Than Encouraged Sectoral Development? International Review of Financial Analysis, vol. 53, pp. 48-65. Available at: https://doi.org/10.1016/j.irfa.2017.08.007 (accessed 27 February 2018).

de Chiara A., Livio L., Ponce J. (2018) Flexible and Mandatory Banking Supervision. Journal of Financial Stability, vol. 34, pp. 86-104. Available at: https://doi.org/10.1016/j.jfs.2017.12.002 (accessed 27 February 2018).

Decree of the President of the Republic of Kazakhstan No 25 of 12 April 2011. Available at: https://tengrinews. kz/zakon/prezident_respubliki_kazahstan/hozyaystvennaya_deyatelnost/id-U1100000025/ (accessed 31 May 2019) (in Russian).

Decree of the President of the Russian Federation No 645, 25 July 2013. Available at: http://www.consultant. ru/document/cons_doc_LAW_149853/(accessed 31 May 2019) (in Russian).

Ding C.G., Wu C.-H., Chang P.-L. (2013) The Influence of Government Intervention on the Trajectory of Bank Performance During the Global Financial Crisis: A Comparative Study Among Asian Economies. Journal of Financial Stability, vol. 9, no 4, pp. 556-64. Available at: https://doi.org/10.1016/j.jfs.2012.11.002 (accessed 27 February 2018).

Dzhagityan E. (2015) Puti regionalizacii i nadnacionalizacii bankovskogo regulirovanija v EAJeS [Perspectives of Regionalization and Supranationalization of Banking Regulation in the Eurasian Economic Union in Light of International Experience]. Bankovskoe delo [Banking], no 8, pp. 26-31 (in Russian).

Dzhagityan E. (2017a) Makroprudencial'naja politika v postkrizisnom bankovskom regulirovanii [Macroprudential Policy in Post-Crisis Banking Regulation]. Mirovaja jekonomika i mezhdunarodnye otnoshenija [World Economy and International Relations], vol. 61, no 4, pp. 13-23. Available at: https://doi.org/10.20542/01312227-2017-61-11-13-23 (accessed 27 February 2018) (in Russian).

Dzhagityan E. (2017b) Faktor regionalizacii bankovskogo regulirovanija v formirovanii evrazijskogo mehanizma finansovoj stabil'nosti [Regionalization of Banking Regulation as a Driving Force of the Eurasian Financial Stability Mechanism]. Den'gi i kredit [Russian Journal of Money and Finance], no 7, pp. 31-40 (in Russian).

Erol S., Ordoñez G. (2017) Network Reactions to Banking Regulations. Journal of Monetary Economics, vol. 89, pp. 51-67. Available at: https://doi.org/10.1016/j.jmoneco.2017.03.005 (accessed 27 February 2018).

Eurasian Economic Union (EAEU) (2014) Treaty on the Eurasian Economic Union. Astana, 29 May. Available at: https://www.wto.org/english/thewto_e/acc_e/kaz_e/WTACCKAZ85_LEG_1.pdf (accessed 1 June 2019).

European Banking Authority (EBA) (n. d.) Official Site of the European Banking Authority. Available at: https://eba.europa.eu/ (accessed 1 June 2019). 
European Central Bank (ECB) (n. d.) Official Site of the European Central Bank. Available at: https://www. ecb.europa.eu/home/html/index.en.html (accessed 1 June 2019).

European Commission (EC) (n. d.) European System of Financial Supervision. Available at: https://ec.europa. eu/info/business-economy-euro/banking-and-finance/financial-supervision-and-risk-management/european-system-financial-supervision_en (accessed 1 June 2019).

European Insurance and Occupational Pensions Authority (EIOPA) (n. d.) Official Site of the European Insurance and Occupational Pensions Authority. Available at: https://eiopa.europa.eu/ (accessed 1 June 2019).

European Securities and Markets Authority (ESMA) (n. d.) Official Site of the European Securities and Markets Authority. Available at: https://www.esma.europa.eu/ (accessed 1 June 2019).

European Systemic Risk Board (ESRB) (n. d.) Official Site of the European Systemic Risk Board. Available at: https://www.esrb.europa.eu/home/html/index.en.html (accessed 1 June 2019).

Federal Deposit Insurance Corporation (FDIC) (n. d.) Official Site of the Federal Deposit Insurance Corporation. Available at: https://www5.fdic.gov/idasp/advSearchLanding.asp (accessed 1 June 2019).

Financial Stability Board (FSB) (2017) 2017 List of Systemically Important Banks. Available at: http://www. fsb.org/wp-content/uploads/P211117-1.pdf (accessed 2 February 2018).

Goldbach R. (2015) Asymmetric Influence in Global Banking Regulation: Transnational Harmonization, the Competition State, and the Roots of Regulatory Failure. Review of International Political Economy, vol. 22, no 6, pp. 1087-127. Available at: https://doi.org/10.1080/09692290.2015.1050440 (accessed 2 February 2018).

Grigor'ev L.M. (2013) Scenarii razvitija i jekonomicheskie instituty [Scenarios of Development and Economic Institutions]. Jekonomicheskaja politika, no 3, pp. 33-60 (in Russian).

Hagendorff J. (2013) Board Monitoring, Regulation, and Performance in the European Banking Industry. Size, Risk, and Governance in European Banking (J. Hagendorff, K. Keasey, F. Vallascas (eds)). Oxford: Oxford University Press.

Heathcote J., Perri F. (2004) Financial Globalization and Real Regionalization. Journal of Economic Theory, vol. 119, no 1, pp. 207-43. Available at: https://doi.org/10.1016/j.jet.2003.06.003 (accessed 2 February 2018).

Hirata H., Ayhan Kose M., Otrok C. (2013) Regionalization vs. Globalization. IMF Working Paper WP/13/19, International Monetary Fund. Available at: https://www.imf.org/external/pubs/ft/wp/2013/wp1319.pdf (accessed 8 February 2018).

Howarth D., Quaglia L. (2016) Internationalised Banking, Alternative Banks and the Single Supervisory Mechanism. West European Politics, vol. 39, no 3, pp. 438-61. Available at: https://doi.org/10.1080/01402382. 2016.1143241 (accessed 27 February 2018).

Hoxha I., Kalemli-Ozcan S., Vollrath D. (2013) How Big Are the Gains from International Financial Integration? Journal of Development Economics, vol. 103, pp. 90-8. Available at: https://doi.org/10.1016/j.jdeveco.2013.02.003 (accessed 27 February 2018).

International Monetary Fund (IMF) (n. d.) IMF Macroeconomic and Financial Data. Available at: http:// data.imf.org/?sk=388DFA60-1D26-4ADE-B505-A05A558D9A42 (accessed 1 June 2019).

Jeong K.-Y., Kim E. (2010) The Global Financial Crisis: New Implications and Perspectives for Emerging Economies. Global Economic Review, vol. 39, no 1, pp. 1-13. Available at: https://doi.org/10.1080/12265081003696379 (accessed 2 February 2018).

Kalemli-Ozcan S., Papaioannou E., Peydró J.-L. (2010) Financial Regulation, Financial Globalization and the Synchronization of Economic Activity. Working Paper Series No 1221, European Central Bank. Available at: http:// citeseerx.ist.psu.edu/viewdoc/download?rep=rep1\&type=pdf\&doi=10.1.1.178.3310 (accessed 15 March 2018).

Kalemli-Ozcan S., Papaioannou E., Peydró J.-L. (2013) Financial Regulation, Financial Globalization and the Synchronization of Economic Activity. The Journal of Finance, vol. 68, no 3, pp. 1179-228. Available at: https://doi.org/10.1111/jofi.12025 (accessed 27 February 2018).

Lane P.R. (2012) Financial Globalisation and the Crisis. BIS Working Paper No 397, Bank for International Settlements. Available at: https://www.bis.org/publ/work397.pdf (accessed 22 March 2018).

Llewellyn D.T. (2006) Institutional Structure of Financial Regulation and Supervision: The Basic Issues. Paper presented at a World Bank seminar, Washington DC, 6-7 June. Available at: http://siteresources.worldbank. 
org/INTTOPCONF6/Resources/2057292-1162909660809/F2FlemmingLlewellyn.pdf (accessed 27 February 2018).

Ministry of Finance of the Republic of Belarus (n. d.) Official Site of the Ministry of Finance of the Republic of Belarus. Available at: http://www.minfin.gov.by/en/ (accessed 31 May 2019).

Mwenda K.K. (2006) Legal Aspects of Financial Services Regulation and the Concept of a Unified Regulator. Law, Justice, and Development Series, The World Bank, Washington DC. Available at: http://siteresources. worldbank.org/INTAFRSUMAFTPS/Resources/Legal_Aspects_of_Financial_Sces_Regulations.pdf (accessed 27 February 2018).

National Bank of the Kyrgyz Republic (n. d.) Official Site of the National Bank of the Kyrgyz Republic. Available at: https://www.nbkr.kg/index.jsp?lang=ENG (accessed 31 May 2019).

National Bank of the Republic of Belarus (n. d.) Official Site of the National Bank of the Republic of Belarus. Available at: https://www.nbrb.by/engl (accessed 31 May 2019).

National Bank of the Republic of Kazakhstan (n. d.) About the National Bank. Available at: https://nationalbank.kz/?docid=1\&switch=english (accessed 31 May 2019).

Prasad E.S., Rajan R.G. (2009) A Pragmatic Approach to Capital Account Liberalization. Journal of Economic Perspectives, vol. 22, no 3, pp. 149-72. Available at: https://doi.org/10.1257/jep.22.3.149 (accessed 2 February 2018).

Rodrik D. (2000) How Far Will International Economic Integration Go? Journal of Economic Perspectives, vol. 14, no 1, pp. 177-86. Available at: https://doi.org/10.1257/jep.14.1.177 (accessed 2 February 2018).

Shirov A.A., Gusev M.S. (2013) Prognozirovanie dinamicheskih i strukturnyh harakteristik razvitija Edinogo jekonomicheskogo prostranstva [Forecasting of Dynamic and Structural Characteristics of the Development of the Common Economic Area]. Problemy prognozirovanija, no 3 (138), pp. 3-15 (in Russian).

Single Resolution Board (SRB) (n. d.) Single Resolution Mechanism (SRM). Available at: https://srb.europa. eu/ (accessed 1 June 2019).

Spendzharova A.B. (2017) Regulatory Cascading: Limitations of Policy Design in European Banking Structural Reforms. Policy and Society, vol. 35, no 3, pp. 227-37. Available at: https://doi.org/10.1016/j.polsoc.2016.09.001 (accessed 2 February 2018).

Spendzharova A.B., Versluis E., Radulova E., Flöthe L. (2016) Too Much, Too Fast? The Sources of Banks' Opposition to European Banking Structural Reforms. Journal of Banking Regulation, vol. 17, no 1-2, pp. 13345. Available at: https://doi.org/10.1057/jbr.2015.16 (accessed 2 February 2018).

State Service of Regulation and Supervision of the Financial Market at the Government of the Kyrgyz Republic (State Financial Supervision Agency) (n. d.) Official Site of the State Service of Regulation and Supervision of the Financial Market at the Government of the Kyrgyz Republic. Available at: http://fsa.kg/\#/home (accessed 31 May 2019).

Tsingou E. (2007) Transnational Private Governance and the Basel Process: Banking Regulation and Supervision, Private Interests, and Basel II. Transnational Private Governance and Its Limits (J.-C. Graz, A. Nölke (eds)). London: Routledge.

Underhill G.R.D., Zhang X. (2008) Setting the Rules: Private Power, Political Underpinnings, and Legitimacy in Global Monetary and Financial Governance. International Affairs, vol. 84, no 3, pp. 535-54. Available at: https://doi.org/10.1111/j.1468-2346.2008.00723.x (accessed 2 February 2018).

World Bank Group (2018) Bankers Without Borders. Global Financial Development Report 2017/2018. Available at: https://openknowledge.worldbank.org/bitstream/handle/10986/28482/9781464811487.pdf (accessed 31 May 2019).

Ycharts (n. d.) The Modern Financial Data Research Platform. Available at: https://ycharts.com/companies/ BCS/assets (accessed 1 June 2019).

Yue L.Q., Luo J., Ingram P. (2013) The Failure of Private Regulation: Elite Control and Market Crises in the Manhattan Banking Industry. Administrative Science Quarterly, vol. 58, no 1, pp. 37-68. Available at: https:// doi.org/10.1177/0001839213476502 (accessed 2 February 2018).

Zuev V.N. (2011) Nadnacional'nyj mehanizm v teorii integracii [Supranational Mechanism in Integration Theory]. Mirovaja jekonomika i mezhdunarodnye otnoshenija, no 4, pp. 30-8 (in Russian). 


\title{
Перспективы и риски формирования институциональной структуры банковского регулирования в ЕАЭС 1
}

\author{
Э.П. Джагитян
}

Джагитян Эдуард Павлович - к.э.Н., доцент Департамента мировой экономики факультета мировой экономики и мировой политики Национального исследовательского университета «Высшая школа экономики»; Российская Федерация, 101000, Москва, ул. Мясницкая, д. 20; E-mail: edzhagityan@hse.ru

Посткризисные преобразования в сфере международного банковского регулирования, известные как Базель III, оставляют нерешенным ряд институциональных аспектов реформы, что ставит под сомнение эффективность функции международного финансового посредничества для обеспечения устойчивого экономического роста. С другой стороны, отсутствие перспектив внедрения стандартов Базеля III в глобальном масштабе на фоне интернационализации банковской деятельности является одной из главных причин регулятивных асимметрий, которые трудно разрешить на национальном уровне. В этих условиях сближение национальных механизмов банковского регулирования и формирование региональной регулятивной конструкции - одна из центральных задач правительств и регуляторов по защите банковских секторов от системных рисков, о чем свидетельствует единый надзорный механизм в странах еврозоны.

Укрепление стрессоустойчивости банковских секторов ЕАЭС и активное вовлечение банков в орбиту задач евразийской экономической интеграции потребуют формирования региональной системы банковского регулирования и надзора. Вместе с тем, поскольку разнорежимность национальных регулятивных механизмов может препятствовать формированию механизма евразийского регулирования банковской сферы в отсутствие наднациональных институтов регулирования, запуск регулятивного механизма в ЕАЭС зависит от того, будет ли формат «мини-Базель III», согласованный государствами - членами ЕАЭС в качестве методологического ядра регионализации и наднационализации, способствовать разрешению регулятивной трилеммы между возможностями, востребованностью и потенциалом наднационализации.

Институциональный аспект «мини-Базеля III» объективно сопряжен с вопросом полноформатности будущего наднационального органа по регулированию финансового рынка ЕАЭС, однако издержки сближения могут превысить преимущества моноинституциональной архитектуры регулирования вследствие реальных и неявных рисков разнорежимности национальных моделей регулирования. В этой связи мы рассматриваем альтернативные сиенарии формирования механизма банковского регулирования в ЕАЭС, которые могут быть востребованы с точки зрения оптимизации логистики регулирования и алгоритмов сближения его национальных механизмов. На основе систематизации преимуществ и рисков каждого из сценариев и сравнительного анализа их состоятельности по обеспечению континуума функции финансового посредничества и достижения финансовой стабильности в ЕАЭС мы пришли к выводу об отсутствии в настоящее время каких-либо приоритетных путей формирования наднациональной регулятивной архитектуры в ЕАЭС. Вместе с тем интеграционным ориентиром сближения и ориентиром наднационализации могло бы стать сходство структуры национальных банковских секторов и выбор наименее затратного сценария, но при условии дополнения предполагаемого наднационального органа по регулированию финансового рынка ЕАЭС органом по координации процесса регулятивного сближения.

Ключевые слова: международное банковское регулирование; институты банковского регулирования; Базель III; «мини-Базель III»; интеграция; наднационализация; системные риски; ЕАЭС

Для цитирования: Джагитян Э.П. (2019) Перспективы и риски формирования институциональной структуры банковского регулирования в ЕАЭС // Вестник международных организаций. Т. 14. № 2. С. $212-237$ (на русском и английском языках). DOI: 10.17323/1996-7845-2019-02-10.

${ }^{1}$ Статья поступила в редакцию в апреле 2018 г.

Данная статья подготовлена при грантовой поддержке проекта «Экономические и институциональные аспекты формирования механизма банковского регулирования в ЕАЭС», выполненного в рамках программы исследований факультета мировой экономики и мировой политики НИУ ВШЭ в 2018 г. 


\section{Источники}

Григорьев Л.М. (2013) Сценарии развития и экономические институты // Экономическая политика. № 3. C. 33-60.

Джагитян Э.П. (2015) Пути регионализации и наднационализации банковского регулирования в ЕАЭС // Банковское дело. № 8. С. 26-31.

Джагитян Э.П. (2017а) Макропруденциальная политика в посткризисном банковском регулировании // Мировая экономика и международные отношения. Т. 61. № 4. С. 13-23. Режим доступа: https://doi. org/10.20542/0131-2227-2017-61-11-13-23 (дата обращения: 31.05.2019).

Джагитян Э.П. (2017b) Фактор регионализации банковского регулирования в формировании евразийского механизма финансовой стабильности // Деньги и кредит. № 7. С. 31-40.

Широв А.А., Гусев М.С. (2013) Прогнозирование динамических и структурных характеристик развития единого экономического пространства // Проблемы прогнозирования. № 3 (138). С. $3-15$.

Зуев В.Н. (2011) Наднациональный механизм в теории интеграции // Мировая экономика и международные отношения. № 4. С. 30-38.

Agénor P.-R. (2003) Benefits and Costs of International Financial Integration: Theory and Facts // The World Economy. Vol. 26. No. 8. P. 1089-1118.

Aikins S. (2009) Global Financial Crisis and Government Intervention: A Case for Effective Regulatory Governance // International Public Management Review. Vol. 10. No. 2. P. 23-43. Режим доступа: https://ssrn. com/abstract=2689183 (дата обращения: 31.05.2019).

Bank for International Settlements (BIS) (2012a) Core Principles for Effective Banking Supervision. Basel Committee on Banking Supervision. Режим доступа: https://www.bis.org/publ/bcbs230.pdf (дата обращения: 31.05.2019).

Bank for International Settlements (BIS) (2012b) Household Indebtedness: Context, Consequence \& Correction. Address by Mr. Patrick Honohan, Governor of the Central Bank of Ireland, to the Limerick Law Society, University of Limerick, Limerick. 14 March. Режим доступа: http://www.bis.org/review/r120315b. pdf?frames $=0$ (дата обращения: 27.02.2018).

Bank for International Settlements (BIS) (2017) Finalising Basel III. Basel Committee on Banking Supervision (BCBS). Режим доступа: https://www.bis.org/bcbs/publ/d424_inbrief.pdf (дата обращения: 20.03.2018).

Bank for International Settlements (BIS) (2018) Keynote Speech by Stefan Ingves, Chairman, Basel Committee on Banking Supervision at the Institute for Law and Finance Conference, Goethe University, Frankfurt, 29 January. Режим доступа: https://www.bis.org/speeches/sp180129.pdf (дата обращения: 31.05.2019).

Banki.ru News Agency Ltd. (n. d.) Рейтинги банков. Режим доступа: https://www.banki.ru/banks/ratings/ (дата обращения: 01.06.2019).

Boyer P.C., Kempf H. (2017) Regulatory Arbitrage and the Efficiency of Banking Regulation // Journal of Financial Intermediation. Режим доступа: https://doi.org/10.1016/j.jfi.2017.09.002 (дата обращения: 31.05.2019).

Central Bank of the Republic of Armenia (n. d.) Legal Acts. Режим доступа: https://www.cba.am/en/sitepages/lalaws.aspx (дата обращения: 31.05.2019).

Central Bank of the Russian Federation (Bank of Russia) (n. d.) Official Site of the Central Bank of the Russian Federation (Bank of Russia). Режим доступа: https://www.cbr.ru/eng/ (дата обращения: 31.05.2019).

Corbet S., Larkin C. (2017) Has the Uniformity of Banking Regulation within the European Union Restricted Rather Than Encouraged Sectoral Development? // International Review of Financial Analysis. Vol. 53. P. 48-65. Режим доступа: https://doi.org/10.1016/j.irfa.2017.08.007 (дата обращения: 31.05.2019).

de Chiara A., Livio L., Ponce J. (2018) Flexible and Mandatory Banking Supervision // Journal of Financial Stability. Vol. 34. P. 86-104. Режим доступа: https://doi.org/10.1016/j.jfs.2017.12.002 (дата обращения: 31.05.2019).

Ding C.G., Wu C.-H., Chang P.-L. (2013) The Influence of Government Intervention on the Trajectory of Bank Performance During the Global Financial Crisis: A Comparative Study Among Asian Economies // Jour- 
nal of Financial Stability. Vol. 9. No. 4. P. 556-564. Режим доступа: https://doi.org/10.1016/j.jfs.2012.11.002 (дата обращения: 31.05.2019).

Erol S., Ordoñez G. (2017) Network Reactions to Banking Regulations // Journal of Monetary Economics. Vol. 89. P. 51-67. Режим доступа: https://doi.org/10.1016/j.jmoneco.2017.03.005 (дата обращения: 31.05.2019).

Eurasian Economic Union (EAEU) (2014) Treaty on the Eurasian Economic Union. Astana. 29 May. Режим доступа: https://www.wto.org/english/thewto_e/acc_e/kaz_e/WTACCKAZ85_LEG_1.pdf (дата обращения: 01.06.2019).

European Banking Authority (EBA) (n. d.) Official Site of the European Banking Authority. Режим доступа: https://eba.europa.eu/ (дата обращения: 01.06.2019).

European Central Bank (ECB) (n. d.) Official Site of the European Central Bank. Режим доступа: https:// www.ecb.europa.eu/home/html/index.en.html (дата обращения: 01.06.2019).

European Commission (EC) (n. d.) European System of Financial Supervision. Режим доступа: https:// ec.europa.eu/info/business-economy-euro/banking-and-finance/financial-supervision-and-risk-management/european-system-financial-supervision_en (дата обращения: 01.06.2019).

European Insurance and Occupational Pensions Authority (EIOPA) (n. d.) Official Site of the European Insurance and Occupational Pensions Authority. Режим доступа: https://eiopa.europa.eu/ (дата обращения: 01.06.2019).

European Securities and Markets Authority (ESMA) (n. d.) Official Site of the European Securities and Markets Authority. Режим доступа: https://www.esma.europa.eu/ (дата обращения: 01.06.2019).

European Systemic Risk Board (ESRB) (n. d.) Official Site of the European Systemic Risk Board. Режим доступа: https://www.esrb.europa.eu/home/html/index.en.html (дата обращения: 01.06.2019).

Federal Deposit Insurance Corporation (FDIC) (n. d.) Official Site of the Federal Deposit Insurance Corporation. Режим доступа: https://www5.fdic.gov/idasp/advSearchLanding.asp (дата обращения: 01.06.2019).

Financial Stability Board (FSB) (2017) 2017 List of Systemically Important Banks. Режим доступа: http:// www.fsb.org/wp-content/uploads/P211117-1.pdf (дата обращения: 02.02.2018).

Goldbach R. (2015) Asymmetric Influence in Global Banking Regulation: Transnational Harmonization, the Competition State, and the Roots of Regulatory Failure // Review of International Political Economy. Vol. 22. No. 6. Р. 1087-127. Режим доступа: https://doi.org/10.1080/09692290.2015.1050440 (дата обращения: 02.02.2018).

Hagendorff J. (2013) Board Monitoring, Regulation, and Performance in the European Banking Industry. Size, Risk, and Governance in European Banking / J. Hagendorff, K. Keasey, F. Vallascas (eds). Oxford: Oxford University Press.

Heathcote J., Perri F. (2004) Financial Globalization and Real Regionalization // Journal of Economic Theory. Vol. 119. No. 1. P. 207-43. Режим доступа: https://doi.org/10.1016/j.jet.2003.06.003 (дата обращения: 02.02.2018).

Hirata H., Ayhan Kose M., Otrok C. (2013) Regionalization vs. Globalization. IMF Working Paper WP/13/19, International Monetary Fund. Режим доступа: https://www.imf.org/external/pubs/ft/wp/2013/wp1319.pdf (дата обращения: 08.02.2018).

Howarth D., Quaglia L. (2016) Internationalised Banking, Alternative Banks and the Single Supervisory Mechanism // West European Politics. Vol. 39. No. 3. P. 438-61. Режим доступа: https://doi.org/10.1080/01 402382.2016.1143241 (дата обращения: 08.02.2018).

Hoxha I., Kalemli-Ozcan S., Vollrath D. (2013) How Big are the Gains from International Financial Integration? // Journal of Development Economics. Vol. 103. P. 90-98. Режим доступа: https://doi.org/10.1016/j. jdeveco.2013.02.003 (дата обращения: 08.02.2018).

International Monetary Fund (IMF) (n. d.) IMF Macroeconomic and Financial Data. Режим доступа: http://data.imf.org/?sk=388DFA60-1D26-4ADE-B505-A05A558D9A42 (дата обращения: 01.06.2019).

Jeong K.-Y., Kim E. (2010) The Global Financial Crisis: New Implications and Perspectives for Emerging Economies // Global Economic Review. Vol. 39. No. 1. P. 1-13. Режим доступа: https://doi. org/10.1080/12265081003696379 (дата обращения: 01.06.2019). 
Kalemli-Ozcan S., Papaioannou E., Peydró J.-L. (2010) Financial Regulation, Financial Globalization and the Synchronization of Economic Activity. Working Paper Series No 1221, European Central Bank. Режим доступа: http://citeseerx.ist.psu.edu/viewdoc/download?rep=rep1\&type=pdf\&doi=10.1.1.178.3310 (дата обращения: 15.03.2018).

Kalemli-Ozcan S., Papaioannou E., Peydró J.-L. (2013) Financial Regulation, Financial Globalization and the Synchronization of Economic Activity // The Journal of Finance. Vol. 68. No. 3. P. 1179-228. Режим доступа: https://doi.org/10.1111/jofi.12025 (дата обращения: 15.03.2018).

Lane P.R. (2012) Financial Globalisation and the Crisis. BIS Working Paper No 397, Bank for International Settlements. Режим доступа: https://www.bis.org/publ/work397.pdf (дата обращения: 22.03.2018).

Llewellyn D.T. (2006) Institutional Structure of Financial Regulation and Supervision: The Basic Issues. Paper presented at a World Bank seminar, Washington DC. 6-7 June. Режим доступа: http://siteresources. worldbank.org/INTTOPCONF6/Resources/2057292-1162909660809/F2FlemmingLlewellyn.pdf (дата обращения: 27.02.2018).

Ministry of Finance of the Republic of Belarus (n. d.) Official Site of the Ministry of Finance of the Republic of Belarus. Режим доступа: http://www.minfin.gov.by/en/ (дата обращения: 31.05.2019).

Mwenda K.K. (2006) Legal Aspects of Financial Services Regulation and the Concept of a Unified Regulator. Law, Justice, and Development Series, The World Bank, Washington DC. Режим доступа: http://siteresources.worldbank.org/INTAFRSUMAFTPS/Resources/Legal_Aspects_of_Financial_Sces_Regulations. pdf (дата обращения: 27.02.2018).

National Bank of the Kyrgyz Republic (n. d.) Official Site of the National Bank of the Kyrgyz Republic. Режим доступа: https://www.nbkr.kg/index.jsp?lang=ENG (дата обращения: 31.05.2019).

National Bank of the Republic of Belarus (n. d.) Official Site of the National Bank of the Republic of Belarus. Режим доступа: https://www.nbrb.by/engl (дата обращения: 31.05.2019).

National Bank of the Republic of Kazakhstan (n. d.) About the National Bank. Режим доступа: https://nationalbank.kz/?docid=1\&switch=english (дата обращения: 31.05.2019).

Prasad E.S., Rajan R.G. (2009) A Pragmatic Approach to Capital Account Liberalization // Journal of Economic Perspectives. Vol. 22. No. 3. Р. 149-72. Режим доступа: https://doi.org/10.1257/jep.22.3.149 (дата обращения: 31.05.2019).

Rodrik D. (2000) How Far Will International Economic Integration Go? // Journal of Economic Perspectives. Vol. 14. No. 1. Р. 177-86. Режим доступа: https://doi.org/10.1257/jep.14.1.177 (дата обращения: 27.02.2018).

Single Resolution Board (SRB) (n. d.) Single Resolution Mechanism (SRM). Режим доступа: https://srb. europa.eu/ (дата обращения: 01.06.2019).

Spendzharova A.B. (2017) Regulatory Cascading: Limitations of Policy Design in European Banking Structural Reforms // Policy and Society. Vol. 35. No. 3. P. 227-37. Режим доступа: https://doi.org/10.1016/j. polsoc.2016.09.001 (дата обращения: 01.06.2019).

Spendzharova A.B., Versluis E., Radulova E., Flöthe L. (2016) Too Much, Too Fast? The Sources of Banks' Opposition to European Banking Structural Reforms // Journal of Banking Regulation. Vol. 17. No. 1-2. P. 133-45. Режим доступа: https://doi.org/10.1057/jbr.2015.16 (дата обращения: 01.06.2019).

State Service of Regulation and Supervision of the Financial Market at the Government of the Kyrgyz Republic (State Financial Supervision Agency) (n. d.) Official Site of the State Service of Regulation and Supervision of the Financial Market at the Government of the Kyrgyz Republic. Режим доступа: http://fsa.kg/\#/home (дата обращения: 31.05.2019).

Tsingou E. (2007) Transnational Private Governance and the Basel Process: Banking Regulation and Supervision, Private Interests, and Basel II. Transnational Private Governance and Its Limits / J.-C. Graz, A. Nölke (eds). L.: Routledge. P. 58-68.

Underhill G.R.D., Zhang X. (2008) Setting the Rules: Private Power, Political Underpinnings, and Legitimacy in Global Monetary and Financial Governance // International Affairs. Vol. 84. No. 3. P. 535-54. Режим доступа: https://doi.org/10.1111/j.1468-2346.2008.00723.x (дата обращения: 31.05.2019).

World Bank Group (2018) Bankers without Borders. Global Financial Development Report 2017/2018. Режим доступа: https://openknowledge.worldbank.org/bitstream/handle/10986/28482/9781464811487.pdf (дата обращения: 31.05.2019). 
Ycharts (n. d.) The Modern Financial Data Research Platform. Режим доступа: https://ycharts.com/companies/BCS/assets (дата обращения: 01.06.2019).

Yue L.Q., Luo J., Ingram P. (2013) The Failure of Private Regulation: Elite Control and Market Crises in the Manhattan Banking Industry // Administrative Science Quarterly. Vol. 58. No. 1. P. 37-68. Режим доступа: https://doi.org/10.1177/0001839213476502 (дата обращения: 01.06.2019). 